\title{
Chemically-resolved aerosol volatility measurements from two megacity field studies
}

\author{
J. A. Huffman ${ }^{1,2,{ }^{*} \text {, K. S. Docherty }}{ }^{1}$, A. C. Aiken ${ }^{1,2}$, M. J. Cubison ${ }^{1}$, I. M. Ulbrich ${ }^{1,2}$, P. F. DeCarlo ${ }^{1, * *}$, D. Sueper ${ }^{1,3}$, \\ J. T. Jayne ${ }^{3}$, D. R. Worsnop ${ }^{3}$, P. J. Ziemann ${ }^{4}$, and J. L. Jimenez ${ }^{1,2}$ \\ ${ }^{1}$ Cooperative Institute for Research in Environmental Sciences (CIRES), Boulder, Colorado, USA \\ ${ }^{2}$ Department of Chemistry and Biochemistry, University of Colorado, Boulder, Colorado, PSI, USA \\ ${ }^{3}$ Aerodyne Research, Inc., Billerica, Massachusetts, USA \\ ${ }^{4}$ Air Pollution Research Center, University of California-Riverside, USA \\ *now at: Max Planck Institute for Chemistry, Mainz, Germany \\ ** now at: Paul Scherrer Institute (PSI), Villigen, Switzerland
}

Received: 4 December 2008 - Published in Atmos. Chem. Phys. Discuss.: 28 January 2009

Revised: 22 July 2009 - Accepted: 14 August 2009 - Published: 28 September 2009

\begin{abstract}
The volatilities of different chemical species in ambient aerosols are important but remain poorly characterized. The coupling of a recently developed rapid temperature-stepping thermodenuder (TD, operated in the range $54-230^{\circ} \mathrm{C}$ ) with a High-Resolution Time-of-Flight Aerosol Mass Spectrometer (HR-ToF-AMS) during field studies in two polluted megacities has enabled the first direct characterization of chemically-resolved urban particle volatility. Measurements in Riverside, CA and Mexico City are generally consistent and show ambient nitrate as having the highest volatility of any AMS standard aerosol species while sulfate showed the lowest volatility. Total organic aerosol (OA) showed volatility intermediate between nitrate and sulfate, with an evaporation rate of $0.6 \% \cdot \mathrm{K}^{-1}$ near ambient temperature, although OA dominates the residual species at the highest temperatures. Different types of OA were characterized with marker ions, diurnal cycles, and positive matrix factorization (PMF) and show significant differences in volatility. Reduced hydrocarbon-like OA (HOA, a surrogate for primary OA, POA), oxygenated OA (OOA, a surrogate for secondary OA, SOA), and biomass-burning OA (BBOA) separated with PMF were all determined to be semi-volatile. The most aged OOA-1 and its dominant ion, $\mathrm{CO}_{2}^{+}$, consistently exhibited the lowest volatility, with HOA, BBOA, and associated ions for each among the highest. The similar or higher volatility of HOA/POA compared to OOA/SOA contradicts the current representations of OA
\end{abstract}

Correspondence to: J. L. Jimenez

(jose.jimenez@colorado.edu) volatility in most atmospheric models and has important implications for aerosol growth and lifetime. A new technique using the AMS background signal was demonstrated to quantify the fraction of species up to four orders-of-magnitude less volatile than those detectable in the MS mode, which for OA represent $\sim 5 \%$ of the non-refractory (NR) OA signal. Our results strongly imply that all OA types should be considered semivolatile in models. The study in Riverside identified organosulfur species (e.g. $\mathrm{CH}_{3} \mathrm{HSO}_{3}^{+}$ion, likely from methanesulfonic acid), while both studies identified ions indicative of amines (e.g. $\mathrm{C}_{5} \mathrm{H}_{12} \mathrm{~N}^{+}$) with very different volatility behaviors than inorganic-dominated ions. The oxygen-to-carbon ratio of $\mathrm{OA}$ in each ambient study was shown to increase both with TD temperature and from morning to afternoon, while the hydrogen-to-carbon ratio showed the opposite trend.

\section{Introduction}

Aerosols contribute to serious human health effects, climate radiative forcing, visibility reduction, acid and nutrient deposition to ecosystems and agricultural land, and changes in the hydrological cycle. Atmospheric aerosols are complex mixtures of organic and inorganic matter. The inorganic fraction is better understood due to the smaller number of species, fewer sources, and simpler chemistry. Conversely, organic aerosols (OA), which comprise almost half of the submicron particle mass in many environments (Kanakidou et al., 2005; Zhang et al., 2007a), are a complex mixture of compounds originating from a large variety of natural and

Published by Copernicus Publications on behalf of the European Geosciences Union. 
anthropogenic sources (Hallquist et al., 2009; de Gouw and Jimenez, 2009). Primary OA (POA) is emitted directly to the atmosphere, mostly by combustion processes, whereas secondary OA (SOA) is formed in the atmosphere from products of oxidation reactions of volatile organic compounds (VOCs). Recent studies indicate that current atmospheric models substantially underestimate SOA formation in polluted regions (Heald et al., 2005; Volkamer et al., 2006; Zhang et al., 2007a). The thousands of species that make up OA have a wide range of properties (e.g., polarity, volatility, molecular mass) making characterization difficult by direct speciation techniques which can only directly identify about $10 \%$ of ambient OA mass as individual compounds (Rogge et al., 1993). Recently developed instruments such as the Aerosol Mass Spectrometer (AMS) (Jayne et al., 2000; Canagaratna et al., 2007) provide a rapid measurement of the OA concentration with some chemical resolution, thus complementing other methods of OA analysis.

The affinities of different chemical components for the gas and particle phases are described by the term "volatility", and are important for a number of reasons. The atmospheric lifetimes and fates of different species are strongly affected by their volatilities because the rates of reaction with atmospheric oxidants and rates of removal by wet and dry deposition depend largely on the phase of a species (Bidleman et al., 1988). An accurate representation of species volatility in models is necessary to predict condensation of semi-volatile species, for example when air is lofted to the cold free troposphere (Kanakidou et al., 2005). Aerosols that are heated or diluted by mixing with cleaner air may evaporate, whether under atmospheric conditions or as a result of measurement. For example, organic compounds emitted from a diesel engine stay preferentially in the condensed phase at high concentrations or low temperatures, but as the emissions are diluted or heated the phase equilibrium shifts to allow a large fraction of the condensed material to evaporate (Lipsky and Robinson, 2006). The measurement of semi-volatile species, therefore, can depend largely on the conditions under which a measurement takes place. Hering and Cass (1999), for example, determined that during summertime sampling periods in Southern California filter measurements lost an average of $61 \%$ of the ammonium nitrate $\left(\mathrm{NH}_{4} \mathrm{NO}_{3}\right)$ mass due to evaporation into gaseous nitric acid and ammonia. Knowledge of particle volatility also allows the estimation of particle mass losses in instruments due to heating, cooling, and pressure changes (Biswas et al., 1987; Meyer et al., 2000) as well as losses due to ram and cabin heating in aircraft sampling (Wilson and Seebaugh, 2001; Bahreini et al., 2003). Recently, Biswas et al. (2009) showed that the production of reactive oxygen species, a surrogate for particle toxicity, is greatly reduced when the semi-volatile fraction was removed from combustion exhaust particles, suggesting that this fraction may be more directly associated with human health effects.

Measurements of aerosol volatility date back over four decades when researchers such as Goetz (1961) measured the loss of deposited particle mass as an underlying plate was exposed to increasing temperature. Different chemical species will evaporate at characteristic temperatures related to their vapor pressures and enthalpies of vaporization (Kreidenweis et al., 1998; Burtscher et al., 2001), which allows limited chemical composition information to be inferred from physical volatility measurements. Heated aerosol tubes, referred to as thermodenuders (TD) among several other names, have become one of the primary ways that aerosol volatility is routinely measured and are in use by many research groups, paired with a large variety of detecting instrumentation to infer aerosol composition. For example, Volatility Tandem Differential Mobility Analyzers (VTDMA), one of the most common ambient particle volatility instruments (e.g. Orsini et al., 1999; Villani et al., 2007), most commonly utilize a heated metal flow-tube placed between two DMAs to measure particle size change as a function of temperature which may be used to infer size-resolved aerosol chemical composition.

Many other measurement techniques have also been coupled with heated volatilization tubes to indirectly determine chemical composition and have most commonly been applied to infer aerosol sulfate $\left(\mathrm{SO}_{4}^{2-}\right)$ concentrations. Twomey (1968) applied a heated quartz tube in front of a thermal diffusion cloud chamber to measure cloud condensation nuclei $(\mathrm{CCN})$ as a function of temperature and concluded that $\mathrm{CCN}$ in the northeastern United States were primarily composed of ammonium sulfate $\left(\left(\mathrm{NH}_{4}\right)_{2} \mathrm{SO}_{4}\right)$. Pinnick et al. (1987) applied a similar instrument in front of a light-scattering particle counter to infer that $60-98 \%$ of the submicron aerosol was ammonium sulfate or ammonium bisulfate $\left(\mathrm{NH}_{4} \mathrm{HSO}_{4}\right)$ in rural New Mexico. Jennings and O'Dowd (1990) and Clarke (1991) each utilized a form of the heated tube design in front of a light-scattering particle instrument to infer that the fine aerosol in the remote marine environment was also mostly sulfates. Jennings et al. (1994) used the same idea, but increased the thermodenuder temperature to a maximum of $860^{\circ} \mathrm{C}$ in order to measure evaporation of what they inferred to be elemental carbon. Recently several TD designs have been improved to address performance limitations caused by insufficient residence time (Wehner et al., 2002; An et al., 2007) and potential vapor recondensation (Fierz et al., 2007). Huffman et al. (2008) modified the Wehner et al. (2002) design by reducing thermal inertia and improving temperature control to allow for rapid temperature stepping or scanning in order to allow for the measurement of particle volatilities across a wide spectrum of temperatures over a timescale of $1-3 \mathrm{~h}$.

While TD techniques have been utilized widely in both laboratory and ambient particle analysis for decades, almost without exception they have only been able to infer chemical information from the measured changes in physical characteristics with increasing temperature. This has allowed the characterization of species with very different volatilities, such as by separating black carbon or sulfate from 
more volatile species, but has not allowed investigation of the aerosol volatility of many chemical components at one time. In particular, very limited information exists on the absolute and relative volatilities of ambient POA and SOA. Both 1-D and 2-D GC-MS results (Hamilton et al., 2004; Williams et al., 2006) show that the oxygenated species which these techniques can detect in ambient aerosols (which should be dominated by SOA) appear to be more volatile than reduced POA species such as hydrocarbons, based on their earlier elution in the chromatogram using non-polar columns which segregate species by decreasing vapor pressure. Environmental chamber experiments a decade ago clearly showed that SOA is semi-volatile (Odum et al., 1997), and a parameterization based on absorptive partitioning that captures this behavior is included in most SOA models. For historical reasons, however, POA is almost always treated in models as nonvolatile. This is partly because experiments on combustion POA have historically been performed at constant dilution ratios (e.g. Hildemann et al., 1989) instead of the variable ratios that are needed to quantify and identify the importance of semivolatile species (Lipsky and Robinson, 2006). The dilution ratios used in POA quantification experiments typically are $\sim 10-100$, which are much lower than ambient ratios of $\sim 1000-10000$. This may have led to overestimation of POA mass in emission tests, as shown by Lipsky and Robinson (2006). These authors also show that POA from diesel exhaust and wood smoke is strongly semi-volatile, with a large fraction of the POA evaporating upon dilution with clean air. Robinson et al. (2007) extended these results to include the photochemical aging of the evaporated POA, which they refer to as "semi-volatile organic compounds (SVOCs)", and of gas-phase compounds with volatilities just above that of undiluted POA, which they refer to as "intermediate volatility organic compounds (IVOCs)." They concluded that this process makes SOA the dominant contributor to regional $\mathrm{OA}$, in agreement with AMS observations (Zhang et al., 2005b, 2007a). (See Appendix A in the Supp. Info. section for a summary of the terms and definitions involving organic aerosol species, http://www.atmos-chem-phys.net/9/ 7161/2009/acp-9-7161-2009-supplement.pdf.)

Primary SVOCs and IVOCs are poorly understood because they are difficult to measure. Information on the relative amounts of SVOCs emitted from sources or present in ambient OA can be inferred from measurement of aerosol evaporation upon dilution or heating near ambient temperature (Lipsky and Robinson, 2006). For example, if a large fraction of the aerosol evaporates upon mild heating (e.g. $10^{\circ} \mathrm{C}$ ), it implies that much of the aerosol mass is semivolatile and therefore that a substantial amount of SVOCs is present in the vapor phase to maintain equilibrium with the particle phase. Conversely, if little evaporation occurs upon mild heating it suggests that the aerosol species have low volatility and that the amount of gas-phase species in equilibrium with them is also small.
In this paper we describe measurements that are, to our knowledge, the first direct chemically-resolved measurements of ambient aerosol volatility made in real time. These were made by coupling the recently improved thermodenuder of Huffman et al. (2008) to a High-Resolution Timeof-Flight Aerosol Mass Spectrometer (HR-ToF-AMS) which allowed the acquisition of complete volatility spectra (thermograms) on a time scale shorter than most changes in ambient particle composition.

\section{Experimental}

\subsection{Field operation of thermodenuder-AMS system}

A recently built thermodenuder (TD) was placed upstream of a High-Resolution Time-of-Flight Aerosol Mass Spectrometer (HR-ToF-AMS; Aerodyne Research, Inc.) (DeCarlo et al., 2006; Canagaratna et al., 2007) and a Scanning Mobility Particle Sizer (SMPS Model 3936, TSI Inc.) and operated during two ground-based urban field campaigns. The AMS measures submicron non-refractory (NR) species, operationally defined as those that evaporate at $600^{\circ} \mathrm{C}$ on the AMS vaporizer, which in practice includes organic material and the most abundant inorganic salts in the submicron mode, but excludes crustal material, black carbon, and sea salt. The TD used in this study, based on the previously published design of Wehner et al. (2002), has been described and characterized in detail elsewhere (Huffman et al., 2008; Faulhaber et al., 2009), so only a brief description is given here. While the rapid-cycling ability of this TD and its application to field analysis at a number of temperatures are novel, the physical design is similar to the Wehner et al. (2002) construction, which improved on earlier designs particularly to provide increased residence time for particle evaporation. The instrument used here is slightly more than a meter in length and consists of two sections in series. The heating section consists of a 1 inch OD $(2.5 \mathrm{~cm})$ stainless steel tube, $50 \mathrm{~cm}$ in length, wrapped with three independentlycontrolled heating tapes in series and surrounded by fiberglass insulation encased in a stainless steel shell. The heated region is followed by a denuder that removes volatilized gases by adsorption to the surface of the charcoal. During sampling the ambient flow is dried $(<\sim 20 \% \mathrm{RH})$ and then split into a portion that goes directly to the AMS and other instruments (e.g. SMPS) without heating and another that passes through the TD before entering the AMS. A custom valve system rapidly and automatically switches the flow sampled by the AMS between ambient (un-denuded) and hermally denuded every $10 \mathrm{~min}$ (for the studies presented here, or as low as $1 \mathrm{~min}$ otherwise), depending on the experiment.

The air residence time (RT) calculated as an average plug flow rate at room temperature through the heated section is $21.2 \mathrm{~s}$ (Huffman et al., 2008). This corresponds to $10.6 \mathrm{~s}$ calculated as the minimum time at the centerline of the laminar 
distribution of speeds. A given TD may not have sufficient $\mathrm{RT}$ in the heated region to reach thermodynamic equilibrium and can therefore be susceptible to kinetic limitations due to incomplete evaporation. An et al. (2007) determined that the RT of most other TD designs ( $2 \mathrm{~s}$ or less) was not sufficient to reach equilibrium within the heated sections, however it is also possible that their design did not allow sufficient heating of the particles at the lowest residence times. For example, Eq. (3) of Fierz et al. (2007) indicates that at the maximum flow rate of $10 \mathrm{lpm}$ used by An et al. (2007) a length of $2.65 \mathrm{~m}$ would have been required to compare with previous measurements, versus the actual length of $55 \mathrm{~cm}$. The residence time of our design is $\sim 2 / 3$ of the RT used by An et al. (2007) in their main mode of operation and similar or much longer than nearly all other published TD designs, thus the residence time here should be long enough to avoid major kinetic limitations. It is likely, however, that evaporation equilibrium is not fully achieved at the flow rates of either TD design, and thus aerosol volatility as determined by this technique should be taken as a lower bound. Incomplete evaporation within the heated section could also be affected by differences in input size distributions, as larger particles require more time or hotter temperatures to evaporate. Faulhaber et al. (2009) further characterize the kinetics of particle evaporation in the TD and show that a diameter shift from $200 \mathrm{~nm}$ to $300 \mathrm{~nm}$ increases the evaporation temperature by $\sim 5^{\circ} \mathrm{C}$ for pure oleic acid particles. The mass concentration of ambient aerosol may also influence the evaporation of mass within the TD to some degree, but this effect has been shown to be relatively small over the range of ambient concentrations typical in polluted locations (Faulhaber et al., 2009; Huffman et al., 2009). The AMS detects the non-refractory mass of particles with vacuum aerodynamic diameters less than $1 \mu \mathrm{m}\left(\mathrm{NR}-\mathrm{PM}_{1}\right)$ that has not evaporated after passing through the TD; at successively higher TD temperatures the remaining NR-PM ${ }_{1}$ is further reduced. All TD temperatures shown here are calibrated centerline (CL) temperatures (Huffman et al., 2008).

Rapid valve switching allows for the measurement of time series of aerosol bypassing the TD and thermally denuded at a series of temperatures. During typical ambient sampling the valves continuously and automatically alternate states to allow ten minutes each in the TD and ambient sampling modes and a full temperature cycle of 8 steps between ambient and $230^{\circ} \mathrm{C}$ over $160 \mathrm{~min}$. A time series of the resultant data then shows ambient particle concentrations for ten minutes, interspersed with reduced sample mass during TD treatment (see Fig. 7a of Huffman et al., 2008). All data shown here were corrected for experimentally determined particle number losses within the thermodenuder, due mostly to diffusion and thermophoresis, over the particle size range where submicron mass is important (Huffman et al., 2008). These corrections increase with temperature from $5 \%$ of the mass fraction remaining (MFR) at ambient to $20 \%$ at $230^{\circ} \mathrm{C}$. For example, if $0.1 \mathrm{MFR}$ remains at $230^{\circ} \mathrm{C}$, the loss correction would be $0.02 \mathrm{MFR}$. As a result, the decrease in mass frac- tion remaining as a function of temperature is due primarily to particle mass evaporation.

\subsection{Description of field studies}

The TD system was used in the SOAR-1 and MILAGRO campaigns. Sampling during SOAR-1 (Study of Organic Aerosols in Riverside, Phase 1) took place in July-August 2005 on the University of California-Riverside campus. Riverside is located on the Eastern edge of the Los Angeles (LA) basin, $\sim 80 \mathrm{~km}$ inland from the urban center of LA. The site was chosen in part because of its consistently high aerosol concentration levels, subject to both local emissions and advected aged pollution from LA making it among the most highly polluted regions for PM in the United States (American Lung Association, 2007). SOAR-1 focused on the sources and composition of ambient organic aerosol (OA), using a variety of state-of-the-art chemical and aerosol instrumentation assembled from a number of research groups. Docherty et al. (2008) present a comparison of five different methods for estimating the fraction of SOA during SOAR1 and show that all methods consistently indicate that SOA dominates OA during the campaign, contrary to the conclusions of most previous studies in the region.

The MILAGRO campaign (Megacity Initiative: Local And Global Research Observations) took place in MarchApril 2006 as an umbrella of four coordinated concurrent studies to study the emissions, transformations, and outflow of pollution from the Mexico City region. The results presented here were acquired at the T0 Supersite, which was located inside the urban area north of downtown Mexico City (Aiken et al., 2009a, b). High aerosol concentrations are typically measured in Mexico City, due to the concentrated urban emissions, somewhat reduced dispersion due to the geography surrounded by high mountains, high levels of photochemical activity due to tropical location and high altitude, as well as the influence of biomass burning emissions during the dry season (Salcedo et al., 2006; Molina et al., 2007; DeCarlo et al., 2008). Both studies utilized a HR-ToF-AMS that sampled downstream of the TD and valve system for approximately two weeks as a part of the longer sampling periods.

\subsection{Positive matrix factorization (PMF) analysis}

Positive matrix factorization (PMF) is a mathematical factor analysis tool that allows for the representation of a complex spectral time series into individual components. This type of factor analysis method solves the mass conservation equations by a weighed least squares method assuming a constant mass spectrum (MS) for each component over time, and determines both the MS and time series of any number of factors the user requests, without any a priori assumptions of either mass spectral or time profile (Zhang et al., 2005a, 2007a; Lanz et al., 2007; Ulbrich et al., 2009). Factor analysis of AMS organic spectra can be used to identify 

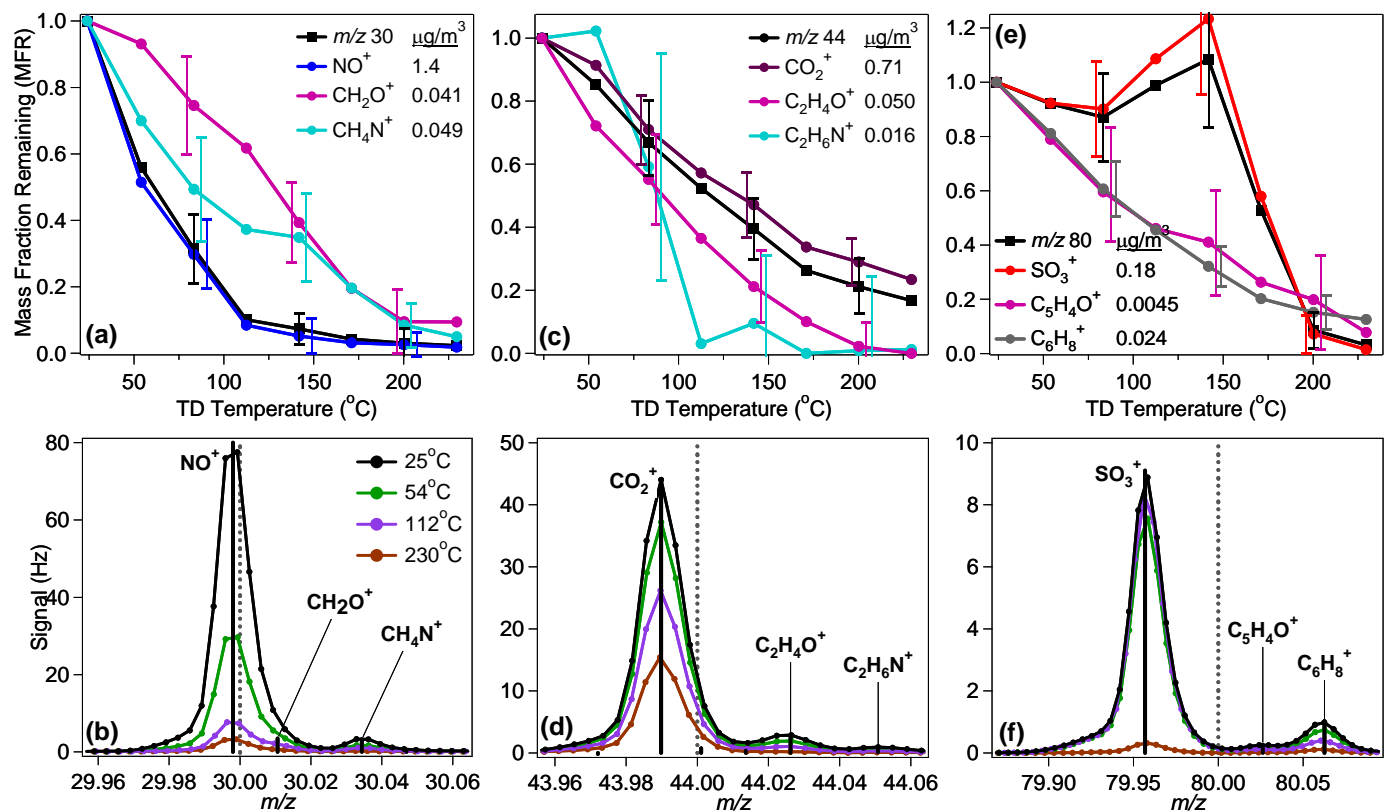

Fig. 1. Top panels show SOAR-1 campaign averages of median mass fraction remaining (MFR) versus temperature ("thermograms"). Each thermogram shows volatilities of ions composing one nominal mass as circular markers, as well as the volatility of the unit mass resolution (UMR) peak shown by black square markers. Average nitrate-equivalent mass concentrations of each ion (defined in Jimenez et al., 2003) are listed in the graph legends. The bottom panels show the high resolution mass spectra for the nominal masses as a function of temperature whose matching ions are shown. The top black curve indicates the ambient MS, while increasing temperature shows decreasing mass signal remaining. The dotted vertical line indicates the nominal mass, with a relative mass defect of zero. (a-b) $\mathrm{m} / \mathrm{z}, 30$, (c-d) $\mathrm{m} / \mathrm{z}^{4} 44,(\mathbf{e}-\mathbf{f}) \mathrm{m} / \mathrm{z}, 80$. Error bars show variability as \pm one standard deviation, calculated over the course of entire campaign (bars are offset for visual clarity).

"components" that reconstruct the total OA, each with a different mass spectrum, diurnal cycle, and volatility profile. These components can be compared with external tracers, spectra, ratios, etc. in order to label them as OA components/sources. HOA (hydrocarbon-like organic aerosol) represents the primary OA (POA) emitted directly to the atmosphere, largely by combustion emissions. It shows a MS dominated by reduced $\mathrm{C}_{\mathrm{x}} \mathrm{H}_{\mathrm{y}}^{+}$ions and a diurnal concentration maximum during the morning rush hour when vehicle emissions are usually highest and when the boundary layer is relatively shallow (Zhang et al., 2005b). OOA (oxygenated organic aerosol), however, is dominated by secondary OA (SOA) (Alfarra et al., 2004; Zhang et al., 2005b, 2007a). Its MS is dominated by oxygenated $\mathrm{C}_{\mathrm{x}} \mathrm{H}_{\mathrm{y}} \mathrm{O}_{\mathrm{z}}^{+}$ions and its diurnal concentration has a broad afternoon peak due to photochemical oxidation of gaseous components (Volkamer et al., 2006, 2007; Herndon et al., 2008; Paredes-Miranda et al., 2009; Aiken et al., 2009a). OOA can be further subdivided into a less oxidized, fresh SOA (OOA-2) which exhibits an afternoon peak, and a more aged SOA (OOA-1) that displays a flatter diurnal profile (Lanz et al., 2007; Nemitz et al., 2008; Aiken et al., 2008; Ulbrich et al., 2009). Biomass burning OA (BBOA) was also important during MILAGRO and had a similar diurnal cycle as HOA, peaking in the early mornings, together with other biomass burning tracers such as acetonitrile (Aiken et al., 2009a). PMF analysis was per- formed on the high-resolution AMS data from both SOAR-1 and MILAGRO to determine components of the ambient OA, following the methodology of Ulbrich et al. (2009). For the analyses presented here, data at all thermal denuder temperatures and also at ambient temperature were run together in PMF. The time series and concentration fractions have been calculated from the results corresponding to the ambient temperature points only.

\section{Results and discussion}

\subsection{Demonstration of method and quantification}

\subsubsection{Chemically-resolved volatility}

Aerosol volatility as characterized by the TD is most conveniently shown by plotting the mass fraction remaining (MFR) in the particle phase downstream of the TD as a function of temperature. These "thermograms" show generally decreasing MFR with increasing temperature, with a defined value of unity at ambient temperature. Figure 1 shows thermograms for three different integer $\mathrm{m} / \mathrm{z}$ values, which are often used as markers for different types of species in the AMS, and for the individual ions fitted from their high-resolution mass spectra (MS) for SOAR-1 campaign averages. Integer $m / z$ signals 


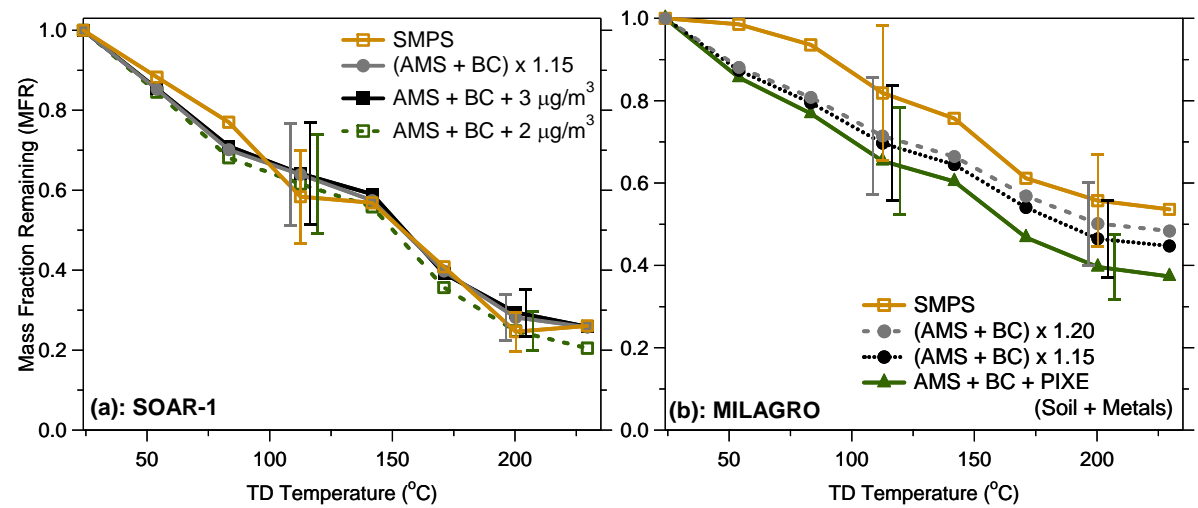

Fig. 2. Volatility comparison of total $\mathrm{PM}_{1}$ aerosol. Total SMPS apparent volume thermogram shown in orange with estimated total mass from AMS + black carbon + crustal materials shown in black curves. Measurements of crustal materials were not performed during SOAR-1 and three different estimates were added to the AMS and BC values in (a) for SOAR-1. Three estimates from both measurements and literature values were added to measured AMS and BC values for MILAGRO in (b). Error bars show estimated accuracy as $\pm 20 \%$ of MFR for each technique at 112 and $200^{\circ} \mathrm{C}$ (bars are offset for visual clarity).

in the MS are averages of all ions at $\mathrm{m} / \mathrm{z}$ and are referred to as Unit Mass Resolution (UMR) signal. These thermograms highlight the ability of the TD-AMS system to differentiate between volatilities of individual ions at a nominal $\mathrm{m} / \mathrm{z}$. For example, the dominant ion in typical ambient spectra at $\mathrm{m} / \mathrm{z}$ 30 is the nitrate fragment $\mathrm{NO}^{+}$, but two other ions, $\mathrm{CH}_{2} \mathrm{O}^{+}$ and $\mathrm{CH}_{4} \mathrm{~N}^{+}$, have a high enough average signal and separation in $\mathrm{m} / \mathrm{z}$ space to allow their individual characterization, as shown in Fig. 1a and b. The thermogram/mass spectra pair shows that even though the $\mathrm{CH}_{2} \mathrm{O}^{+}$ion is in the tail of the larger $\mathrm{NO}^{+}$peak, its thermal behavior is clearly different. The black UMR curve in Fig. 1a is only slightly above the curve for the $\mathrm{NO}^{+}$ion, indicating nearly all of the signal at $\mathrm{m} / \mathrm{z} 30$ is due to the nitrate fragment. The UMR thermogram in each case is just a weighted average of the individual ion thermograms at that $m / z$.

Figure 1c, d shows the thermograms and MS of the ions at $m / z 44$, commonly used as a marker for aged oxygenated organic aerosol (OOA) (Alfarra et al., 2004; Zhang et al., 2005b). Again, the HR MS shows that two other ions contribute a small fraction of the UMR signal in this SOAR-1 average and can be easily analyzed separate from the dominant $\mathrm{CO}_{2}^{+}$ion signal. Figure $1 \mathrm{e}$, f shows $m / z$, which is dominated by the sulfate fragment $\mathrm{SO}_{3}^{+}$. Two organic ions are present that have clearly lower MFR than the sulfate fragment.

\subsubsection{Quantification}

It is important to establish that quantitative results can be obtained from the TD-AMS technique and that the observed signal variations are not dominated, for example, by changes in the AMS particle collection efficiency, in particular due to particle bounce (Huffman et al., 2005; Matthew et al., 2008). The most direct way to address this issue with field data is to compare results from collocated instruments, as has been done for standard (unheated) AMS data (e.g. Drewnick et al., 2003; Takegawa et al., 2005; DeCarlo et al., 2008; Dunlea et al., 2008). Here, we compare thermal desorption profiles of TD-AMS total mass with those from a collocated SMPS system. For the studies described here an SMPS was always operated after the TD in parallel with the AMS. The SMPS records the number size distribution of the aerosol and from these data one can estimate the total apparent particle volume. In order to compare with the TD-AMS, the SMPS total apparent volume was converted to total mass using Eq. (4) from DeCarlo et al. (2004; also Eq. (2) from Salcedo et al., 2006) to estimate the total aerosol density. For a proper comparison, the mass of refractory species (black carbon (BC), dust, metals) must also be accounted for since the AMS only measures NR species. BC during SOAR-1 was added from the measurements of Snyder and Schauer (2007). Concentrations of suspended $\mathrm{PM}_{1}$ crustal material and dust for SOAR1 were estimated to be between 2 and $3 \mu \mathrm{g} / \mathrm{m}^{3}$ based on prior measurements in this region from Christoforou et al. (2000) and Hughes et al. (2000). An estimate of $\sim 15 \%$ crustal material/dust during SOAR-1 was derived by Docherty et al. (2009). The resulting thermograms estimated by adding $\mathrm{BC}$ plus respective estimates of crustal material to the AMS are shown in Fig. 2a, while average size distributions at the different temperatures are shown in Fig. S1 in the Supp. Info. The SMPS thermogram from SOAR-1 is very similar to that estimated from the AMS + refractory data.

During MILAGRO a 3-stage IMPROVE DRUM impactor collected aerosol, which was later analyzed by particleinduced X-ray emission (PIXE) to quantify crustal and metal species (Salcedo et al., 2006; Johnson et al., 2008; Aiken et al., 2009b). The concentration of crustal materials was determined by multiplying the measured mass of each of the elements common in soil (in the nominal size range 
$0.07-1.15 \mu \mathrm{m})$ by a scalar value to estimate the total mass of the metal oxides present (Malm et al., 1994; Aiken et al., 2009b). Non-crustal metals such as $\mathrm{Zn}$ were added to the refractory mass following the same procedure. To obtain an alternative estimate, we used the report from Querol et al. (2008) that $15-28 \%$ of the $\mathrm{PM}_{2.5}$ mass at urban sites in Mexico City during MILAGRO was crustal material with additional trace metals approximately $1 \%$. We added soil plus metal estimates of 15 and $20 \%$ of the mass, respectively, to the measured AMS and black carbon measurements, taking into account that most of the soil mass in $\mathrm{PM}_{2.5}$ is in $\mathrm{PM}_{1}$. All three curves are shown in Fig. $2 b$ in comparison with the average thermogram of the SMPS mass. The MILAGRO comparison shows larger differences than that for SOAR-1 and more dependence on the chosen estimate for crustal and metal material.

There are several possible sources of differences between the TD measurements from the AMS and SMPS, related to the response of either instrument to the thermally denuded particles. First, as particles are heated, they shift to lower size bins in both instruments. Mass present above the upper size cut of the SMPS or beyond the limit of the lens transmission for the AMS can then become available for detection after the particle diameters have been reduced. This effect may be larger for the SMPS which has a "vertical" size cut vs. the more gradual cut in the AMS (Jayne et al., 2000). Second, particles may become irregular as more volatile material on their surface evaporates and reveals, for example, part of the soot cores on which other species had condensed. This effect will lead to an overestimation of the volume in the SMPS since irregular particles are sized larger than their volumeequivalent diameter measured by mobility-based techniques. Even a modest change in the dynamic shape factor from 1 to 1.1 will result in an overestimate by $\sim 25 \%$ of the apparent SMPS volume (DeCarlo et al., 2004), while soot particles can have shape factors as large as 3.5 (Slowik et al., 2004). The bounce-related collection efficiency $\left(E_{b}\right)$ (Huffman et al., 2005) of particles in the AMS may increase or decrease due to the thermal treatment. This topic has not been studied in detail, however. Previous results show a potential change in $E_{b}$ of the order of 10-20\% for ammonium sulfate particles in the temperature range $90-175^{\circ} \mathrm{C}$ during laboratory tests (Huffman et al., 2008), while similar effects are observed for ambient sulfate as described below. Potentially the AMS shape-related collection efficiency $\left(E_{S}\right)$ (Huffman et al., 2005), which is typically close to one for ambient particles (Salcedo et al., 2007), could lead to similar effects if the particles become highly irregular after heating (Huffman et al., 2005, 2008). The fact that only a minor fraction of the non-refractory submicron particle mass is present above the AMS size cut during MILAGRO and SOAR-1 is confirmed by the results of Salcedo et al. (2006), Querol et al. (2008), Aiken et al. (2009b), and Docherty et al. (2008). It would obviously be advantageous to perform size-resolved TD-AMS analysis (with pre-classification using a DMA) to avoid the

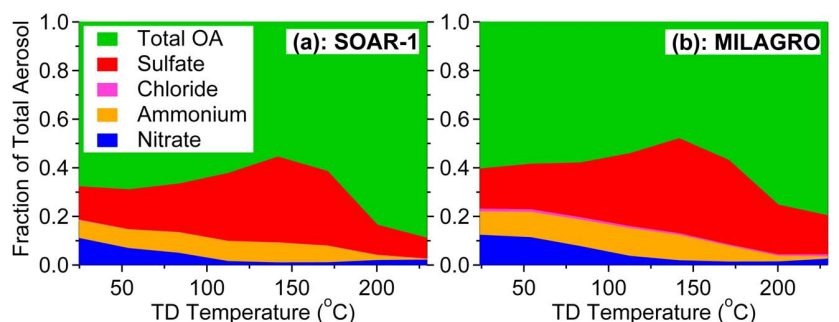

Fig. 3. Fraction of the total aerosol mass contained in each of the standard AMS species (total organic aerosol, sulfate, chloride, ammonium, and nitrate) is shown as a function of temperature for (a) SOAR-1 and (b) MILAGRO.

influence of some of these problems, but when using the average signal ("MS") mode of the high-resolution AMS the signal-to-noise ratio is too low to be useful. Also, when characterizing only one particle size there is a loss of information on the rest of the size distribution, which one has to weight against the potential inaccuracy created by some mass entering the analysis window through the upper end.

Despite the effects that complicate the comparison between the two techniques, the agreement between the reconstructed AMS and SMPS mass for SOAR-1 is good, and the observed differences for MILAGRO are within the nominal accuracies of both techniques. Given the impact of each of the possible biases described above, we estimate the nominal accuracy of each technique at approximately $\pm 20 \%$ of MFR for concentrations at ambient and elevated temperatures (e.g. at an MFR of 0.50 the accuracy is estimated at \pm 0.10 ). We estimate the precision of the technique as $\pm 10 \%$ MFR based on the observed reproducibility of the results. Together with the large differences in volatility between chemical species described below and also in Huffman et al. (2008), we conclude that the differences in the TD-AMS thermograms are dominated by the differences in the relative volatility of the different chemical species. Further research should address each of the effects described above, for example, by carrying out size-resolved experiments to eliminate the effect of the size cuts and directly quantifying changes in shape factor with emerging online techniques (e.g. Zelenyuk et al., 2008), changes in $E_{b}$ using the internal AMS light scattering probe (Cross et al., 2007), and changes in $E_{s}$ using the internal AMS beam width probe (Huffman et al., 2005).

\subsubsection{Species mass fraction}

The relative amount of mass from each NR species is shown in Fig. 3 as a function of temperature. Total OA is more than $50 \%$ of the ambient NR mass for each study, which is typical of many urban aerosol observations (Zhang et al., 2007a). As TD temperature is increased, the relative OA concentration remains significant in both studies while nitrate and ammonium decrease in relative fraction. Sulfate increases in relative fraction to a maximum at $\sim 140^{\circ} \mathrm{C}$ due to its slow evaporation and the smaller effect of increased 

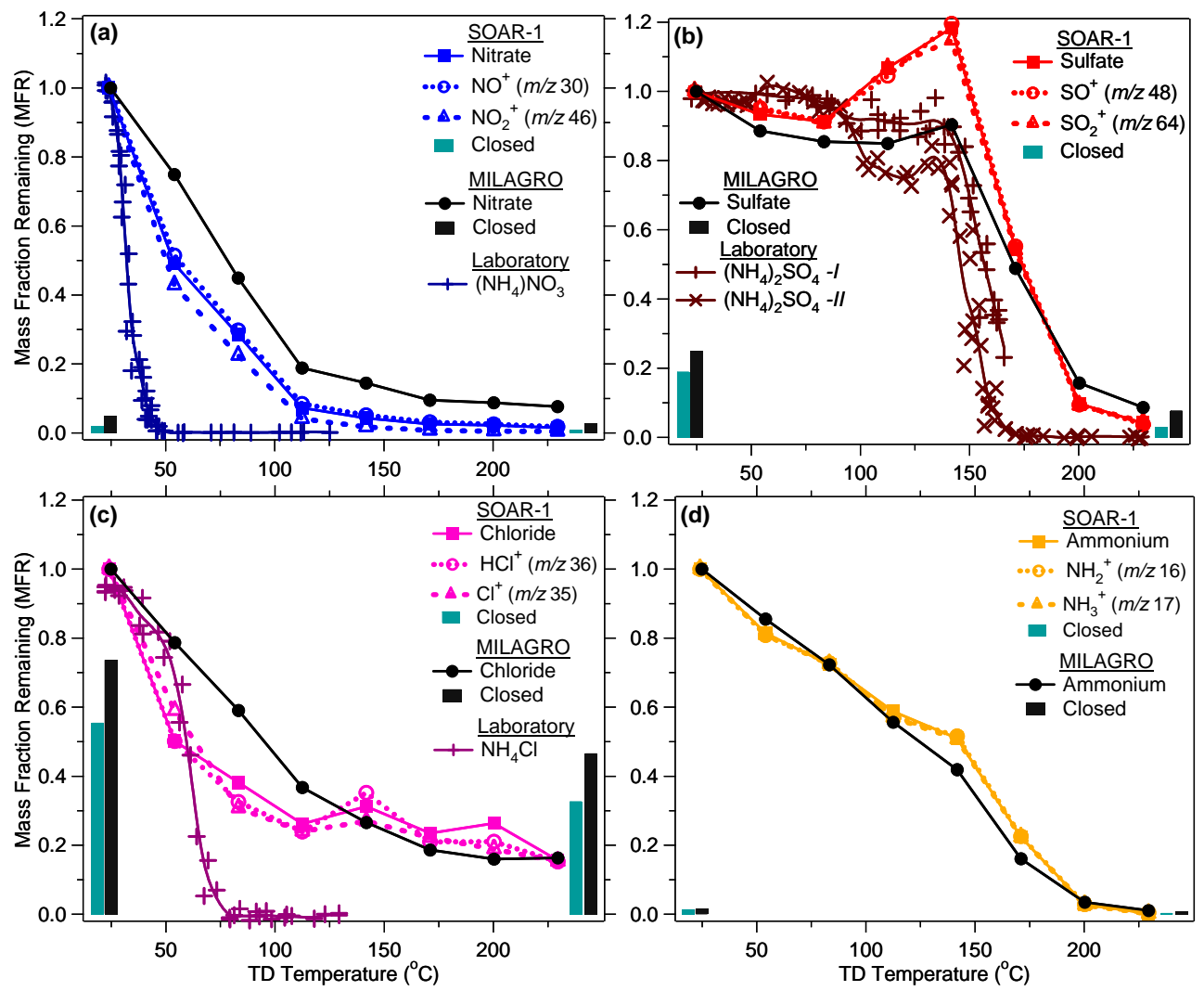

Fig. 4. Thermograms of standard inorganic AMS species are shown. Each panel shows the species total and major constituent ions for SOAR1 as well as the total for MILAGRO as comparison. Ammonium salts of nitrate, sulfate and chloride are shown by cross- or x-markers as lab-calibrated standards for comparison. Bars for both SOAR-1 and MILAGRO indicate the relative enhancement in mass remaining above background for the AMS closed signal at ambient temperature and $230^{\circ} \mathrm{C}$ as compared with the amount of signal in the AMS difference signal at ambient. (a) Nitrate, (b) Sulfate, (c) Chloride, (d) Ammonium.

$C E$ as discussed above. Non-refractory chloride constitutes a very small fraction of the total aerosol mass in both studies. At the hottest set-point in each study OA constitutes 80-90\% of the remaining NR aerosol mass, indicating that some organic species of very low volatility remain, which may have been present before heating or perhaps also formed due to chemistry at the higher TD temperatures (Denkenberger et al., 2007).

\subsection{Inorganic volatility}

\subsubsection{General inorganic observations}

Figure 4 shows a summary of the thermograms of standard AMS inorganic species from SOAR-1 and MILAGRO and the high-resolution ions that contribute to these signals. In each of the four panels of Fig. 4 there is high consistency between the thermograms of the various fragment ions of each inorganic species. In each case the total species, calculated by summing the HR signal of each contributing ion, shows a nearly identical thermogram to each of its major ions. The average of the MILAGRO species calculated in the same way is shown in black for each panel and shows similar behavior from the SOAR-1 averages with smaller differences between the two studies for the same species than are observed for different species in the same study. Note that organic species such as organonitrates and organosulfates can produce nominally inorganic fragments which are indistinguishable within the MS from ions of purely inorganic origin, and thus are lumped together in these analyses. The fraction of these ions arising from organic species, however, is estimated to be small, based on the molar neutralization balance of ammonium vs. sulfate, nitrate, and chloride anions. This is consistent with a recent evaluation that estimates that organosulfates may account for $5-10 \%$ of the organic mass and a smaller fraction of the sulfur mass at 12 US locations (Tolocka and Turpin, 2009).

Figure 4 a shows the average nitrate $\left(\mathrm{NO}_{3}^{-}\right)$volatility, along with that of major contributing ions $\mathrm{NO}^{+}$and $\mathrm{NO}_{2}^{+}$. The MILAGRO nitrate is somewhat less volatile than in SOAR-1. $50 \%$ of the SOAR-1 nitrate mass is reduced by increasing the temperature from ambient to $54^{\circ} \mathrm{C}$. Hering and Cass (1999) reported that for measurements in Southern California during fall and summer periods that 28 and $61 \%$, respectively, of 
ammonium nitrate $\left(\mathrm{NH}_{4} \mathrm{NO}_{3}\right)$ particle mass evaporated from filters during a 4-h collection period, which is broadly consistent with the high volatility observed here for nitrate. Both of the field datasets show a much reduced evaporation of nitrate compared to pure ammonium nitrate measured in the laboratory. This may indicate that the more complex matrix of ambient particles is tying the nitrate more strongly to the particle phase or delaying its evaporation, compared to pure laboratory particles.

The sulfate $\left(\mathrm{SO}_{4}^{2-}\right)$ curves, shown in Fig. $4 \mathrm{~b}$, are qualitatively similar to each other and to the laboratory ammonium sulfate $\left(\left(\mathrm{NH}_{4}\right)_{2} \mathrm{SO}_{4}\right)$ data, except that the MILAGRO sulfate lies somewhat below the SOAR-1 sulfate for most temperatures. The average sulfate thermogram for both SOAR-1 and MILAGRO slowly decreases at low temperatures but then increases to a maximum at $\sim 140^{\circ} \mathrm{C}$. This increase is likely due to a physical change in the sulfate phase or morphology. Larson et al. (1982, Fig. 2a), for example, reported a relative increase in the measured thermogram of normalized light scattering ratio versus thermodenuder temperature for laboratory-generated $\left(\mathrm{NH}_{4}\right)_{2} \mathrm{SO}_{4}$ at similar temperatures and under humid conditions (65-80\% relative humidity). They attributed this increase to the decomposition of $\left(\mathrm{NH}_{4}\right)_{2} \mathrm{SO}_{4}$ into more acidic ammonium bisulfate $\left(\mathrm{NH}_{4} \mathrm{HSO}_{4}\right)$ and gasphase ammonia $\left(\mathrm{NH}_{3}\right)$ upon heating, followed by water uptake by the particles after cooling. We observe a similar thermogram profile with atomized $\left(\mathrm{NH}_{4}\right)_{2} \mathrm{SO}_{4}$ and see a relative increase in MFR for ambient sulfate from $\sim 90-140^{\circ} \mathrm{C}$. The ratio of $\mathrm{NH}_{4}^{+}$to $\mathrm{SO}_{4}^{2-}$ for the ambient sulfate is consistent with this decomposition as discussed below, but the laboratory data showed neutralized particles at all temperatures, which is inconsistent with the Larson et al. (1982) hypothesis. The formation of ammonium bisulfate or other more acidic sulfate forms from ammonium sulfate may cause particles to form more volatile phases, lessening the bounce off the AMS vaporizer and thus increasing the effective collection efficiency (CE) (Huffman et al., 2008; Matthew et al., 2008). A constant $C E$ of 0.5 is typically applied to AMS data based on a large number of inter-comparisons with other techniques (e.g. Drewnick et al., 2003; Takegawa et al., 2005; Zhang et al., 2005b; Salcedo et al., 2006; Canagaratna et al., 2007), except for special cases such as very acidic sulfate particles which are known to be collected with higher efficiency (Quinn et al., 2006; Matthew et al., 2008). If the sulfate becomes more acidic after the TD and is therefore collected more efficiently by the AMS, the $C E$ value would in principle need to be adjusted. For the sulfate thermogram curve to be flat from $83-142^{\circ} \mathrm{C}$ the $C E$ would need to be increased from a constant value of 0.5 to be a function of temperature, rising to 0.65 for SOAR- 1 and to 0.55 for MILAGRO. However, we prefer to present the data as recorded with a constant $C E$ assumption so that the effect can be evaluated, and circular reasoning is avoided. It is also possible that other unknown effects are responsible for some of the observed variation (Huffman et al., 2008). These variations are of the order of $\sim 20 \%$ and do not mask the overall trend of low sulfate volatility when compared to organic and other inorganic species, with a sharp decrease in MFR between 142$171^{\circ} \mathrm{C}$.

The non-refractory chloride $\left(\mathrm{Cl}^{-}\right)$thermograms are shown in Fig. 4c. Chloride during MILAGRO shows less volatility than during SOAR at lower TD temperatures, but a similar MFR at the higher temperatures. The decay at the lower temperatures is consistent with that of ammonium chloride $\left(\mathrm{NH}_{4} \mathrm{Cl}\right)$ in the laboratory, but a substantial amount of material remains at the higher temperatures. This suggests that some of the chloride measured by the AMS at these locations is in the form of ammonium chloride (or other species of similarly high volatility) as concluded previously (Tanaka et al., 2003; Salcedo et al., 2006), but also that at least some of the chloride measured by the AMS is in a less volatile chemical form. This less-volatile chloride may indicate the presence of metal chlorides like lead chloride $\left(\mathrm{PbCl}_{2}\right)$ (Moffet et al., 2008).

The ammonium $\left(\mathrm{NH}_{4}^{+}\right)$thermograms, shown in Fig. 4 d, are very similar for both campaigns. The decay of this species with temperature is consistent with an increase in particle acidity as temperature increases, as discussed above and below. Note that the SOAR-1 curves have small kink at $\sim 140^{\circ} \mathrm{C}$, presumably due to the slightly increased $C E$ as discussed above. The laboratory thermograms for ammonium are identical to the anions they were bonded with in each experiment (Fig. $4 \mathrm{a}-\mathrm{c}$ ) and so were not shown for the sake of avoiding duplicity.

For all species the lab-generated ammonium salts show broadly similar behavior to the observed ambient species, especially at lower temperatures. Most of the ambient species, however, show some residual MFR at high temperatures, in contrast with the laboratory experiments. This is likely due to the fact that pure lab-generated particles are less complex than the internal mixtures found in ambient particles. A given species may be more volatile, but its evaporation may be kinetically limited due to "trapping" inside layers of less volatile material, as suggested by Huffman et al. (2009) for levoglucosan in biomass burning particles. It is also possible that less-volatile chemical forms of these species account for some fraction of their ambient signal, especially for chloride as discussed above. While these effects may smear the volatility transitions somewhat and make the patterns less distinct than in pure, single-compound particles, the observations from ambient particles that inorganic species show very different thermograms from each other indicate that volatility is clearly the dominant differentiating mechanism. Faulhaber et al. (2009) and Saleh et al. (2008) have used thermodenuder data to obtain information about species vapor pressure and volatility. These techniques should be applicable to our TD data, but are beyond the scope of this manuscript.

Also shown in Fig. 4 is the relative amount of material that remains in the AMS signal during the closed phase of the chopper cycle. During MS-mode data acquisition the particle 
beam is blocked at regular intervals in order to quantitatively subtract the residual gas background from the particle signal (Jimenez et al., 2003). It is observed that this background may increase during periods of elevated particle concentration, which can be due to species that evaporate more slowly than the open/close cycle of the AMS chopper (typically 3$5 \mathrm{~s}$ ), or due to slow evaporation of particles that bounce from the AMS vaporizer and land on colder surfaces, e.g. $250^{\circ} \mathrm{C}$ in the ionizer region instead of $600^{\circ} \mathrm{C}$. Thus it is of interest to evaluate the magnitude of this signal, as a qualitative indicator of the presence of less volatile species. This method allows the detection of species which evaporate in the AMS background with timescales of several hours, which allows the detection of species with vapor pressures four orders of magnitude lower than with the 3-5 s used for vaporization in typical AMS analysis. The bars on either side of each panel show the relative enhancement of closed signal (above the background present during periods of low species concentration) remaining at each temperature for both ambient studies. The nitrate and ammonium background enhancements are very small, indicating that very slowly evaporating forms of these species are not present in ambient particles. Sulfate is somewhat higher and shows a larger enhancement at ambient temperature in the TD compared to high temperature. The fraction that remains present in the thermogram at high TD temperature is likely due to slow evaporation inside the AMS, while the difference between the bars at ambient and high temperature is most likely due to particles that bounced off the AMS vaporizer and landed on colder surfaces in the AMS ionizer and whose vapors are sampled less efficiently by the AMS ionization region. The background chloride signals are the highest of the four species, further corroborating the presence of measurable amounts of less volatile species such as $\mathrm{PbCl}_{2}$ or $\mathrm{NaCl}$ in ambient particles. Johnson et al. (2008) show that in Mexico City the AMS detects four times more chloride than is seen by PIXE (particleinduced X-ray emission) techniques. If a major fraction of the chloride was too refractory to be detected in the AMS background, then the PIXE analysis would show considerably more than can be seen by the AMS. The fact that this is not the case strongly suggests that the combination of the NR plus background chloride measurements in the AMS capture all of the submicron chloride in Mexico City.

\subsubsection{Particle acidity}

The average relative particle acidity can be estimated by plotting the measured AMS ammonium concentration (calculated from the HR ions) versus the predicted ammonium concentration, calculated from the HR concentrations of the inorganic anion species (Zhang et al., 2007b) as:

Predicted $\mathrm{NH}_{4}^{+}=18.0 \times\left(2 \times \mathrm{SO}_{4}^{2-} / 96.1+\mathrm{NO}_{3}^{-} / 62.0+\mathrm{Cl}^{-} / 35.5\right)$

A ratio of the predicted to measured ammonium indicates the relative acidity of the particle. A value of unity indi-

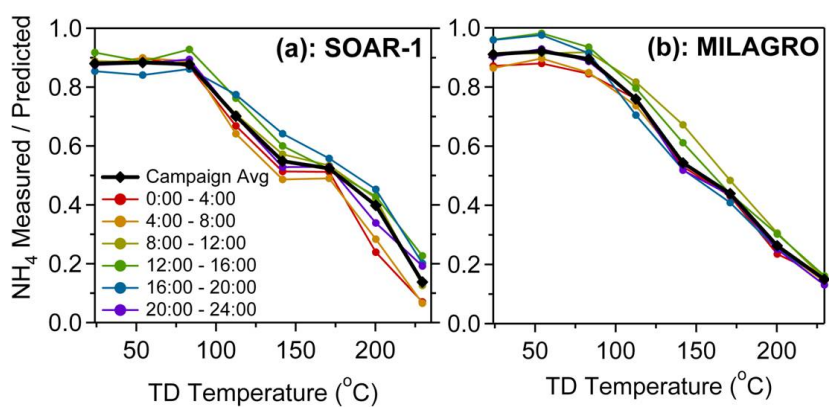

Fig. 5. $\mathrm{NH}_{4}^{+}$measured/predicted ratio (Eq. 1) shown as a function of TD temperature for averages of the total campaign (solid black line) and for six 4-h daily time blocks for (colored lines). Relative acidity increases as measured/predicted ratio decreases. (a) SOAR1 and (b) MILAGRO.

cates full neutralization of ammonium by the inorganic sulfate, nitrate and chloride anions. Values below unity are nominally acidic (i.e. containing some $\mathrm{NH}_{4} \mathrm{HSO}_{4}$ ), which may also be due to the presence of either organosulfates and/or organonitrates, or to inaccuracies in the $\mathrm{NH}_{4}^{+}$calibrations. Figure 5a shows the evolution of the nominal ammonium balance as TD temperature increases for SOAR-1. There is very little noticeable change in average ammonium balance between ambient temperature and $83^{\circ} \mathrm{C}$, but as the TD temperature becomes hotter the particles become increasingly acidic. This is consistent with the possibility that ammonium sulfate is decomposing to yield gas-phase $\mathrm{NH}_{3}$ and acidic $\mathrm{NH}_{4} \mathrm{HSO}_{4}$ (Larson et al., 1982) as discussed above. The nominal acidity increase with temperature is also shown for MILAGRO in Fig. 5b and exhibits similar behavior. The diurnal pattern of the ammonium balance is also shown on the same graph, showing small variations in both cases. Slightly higher nominal acidities are observed early in the morning while lower values are observed in the afternoon, which are consistent with the likely daily variations of the $\operatorname{AMS} E_{b}$, as discussed below.

\subsubsection{Survey of thermograms for inorganic and organic chemical classes}

Full thermograms of MFR versus temperature contain information about the distribution of species volatilities, but data at the lowest $\mathrm{TD}$ temperature of $54^{\circ} \mathrm{C}$ is the most relevant for potential evaporation under ambient conditions. As a way of summarizing the volatility information of the whole HR mass spectrum, Fig. 6 shows the MFR at $54^{\circ} \mathrm{C}$ for many individual HR ions versus $m / z$. The top panels (Fig. 6a, b) show the $\mathrm{N}$ - and S-containing ions (inorganic and organic), colored by type, and the bottom panels (Fig. 6c, d) show organic ions of formulae $\mathrm{C}_{\mathrm{x}} \mathrm{H}_{\mathrm{y}}^{+}$and $\mathrm{C}_{\mathrm{x}} \mathrm{H}_{\mathrm{y}} \mathrm{O}_{\mathrm{z}}^{+}$(hereinafter $\mathrm{CH}^{+}$and $\mathrm{CHO}^{+}$ for short). A threshold was applied to filter out ions with small contributions to the total signal. Ions with low signal which may have some residual interference from the tails of adjacent larger ion peaks in the MS were also removed. 
The $\mathrm{NH}^{+}, \mathrm{HSO}^{+}, \mathrm{HCl}^{+}$, and $\mathrm{NO}^{+}$groups show very consistent behavior within each group in both campaigns, and consistent with the trends discussed above (Fig. 4) for the inorganic species. The $\mathrm{CHN}^{+}, \mathrm{CHON}^{+}$and $\mathrm{CHS}^{+}$signals are significantly smaller, but often have unique thermograms. The differences between these ions at $54^{\circ} \mathrm{C}$ were larger in SOAR-1 than during MILAGRO. The organosulfur ions $\mathrm{CHS}^{+}$(nominal mass $\mathrm{m} / \mathrm{z}$ 45), $\mathrm{CH}_{3} \mathrm{SO}_{2}^{+}(\mathrm{m} / \mathrm{z}, 79)$ and $\mathrm{CH}_{3} \mathrm{HSO}_{3}^{+}(\mathrm{m} / z$ 86) were each detectable in most periods of SOAR-1 and show substantially increased volatility (when the whole thermograms is considered, e.g. Fig. 7b) as compared with inorganic sulfate ions. However, the MFRs of these ions at the lower temperatures (also Fig. S2) do not deviate significantly from the inorganic sulfate ions present in higher concentrations. During SOAR-1 several ions of the $\mathrm{CHN}^{+}$ion group had relatively low MFR which decreased with $\mathrm{m} / \mathrm{z}$, in line with nitrate and chloride ions but substantially lower than all other organic ions. During MILAGRO this ion group (as well as the $\mathrm{CHNO}^{+}$group, which was detected clearly during MILAGRO but not SOAR-1) shows a very different behavior than during SOAR-1 and more similar to that of the $\mathrm{CH}^{+}$and $\mathrm{CHO}^{+}$ions. This may be due to different parent species contributing to these ions at these two locations, or to differences in the mixing states of these minor species. Figure $6 \mathrm{c}$ and $\mathrm{d}$ will be discussed in a following section.

\subsubsection{Nitrogen- and sulfur-containing organic ions}

Figure 7 shows thermograms and diurnal trends for a few key nitrogen- and sulfur-containing organic ions for SOAR1. A number of ions in these classes were detectable, and Fig. 7a shows campaign averages of $\mathrm{CH}_{4} \mathrm{~N}^{+}(\mathrm{m} / \mathrm{z}, 30)$ and $\mathrm{C}_{5} \mathrm{H}_{12} \mathrm{~N}^{+}(\mathrm{m} / z$ 86). These ions were chosen because of their high relative signals as compared with other similar ions and because the thermograms and the diurnal thermogram patterns of other similar ions show similar behavior. $\mathrm{NO}_{2}^{+}$is shown as an example of the ammonium nitrate-dominated ions, whose thermogram is similar to that of $\mathrm{C}_{5} \mathrm{H}_{12} \mathrm{~N}^{+}$below the $83^{\circ} \mathrm{C}$ temperature point, but shows lower MFR at $112^{\circ} \mathrm{C}$ and above. The $\mathrm{NO}_{2}^{+}$average thermogram reaches zero by $\sim 171^{\circ} \mathrm{C}$, but both $\mathrm{N}$-containing organic ions continue to show some remaining signal, especially $\mathrm{CH}_{4} \mathrm{~N}^{+}$, which shows $\sim 10 \%$ MFR at the hottest recorded temperature. The inorganic-dominated $\mathrm{NO}_{2}^{+}$shows little change from morning to afternoon. The $\mathrm{CH}_{4} \mathrm{~N}^{+}$ion, however, shows somewhat more diurnal variability, with lower MFR in the mornings and higher in the afternoons. The diurnal volatility trend of the $\mathrm{C}_{5} \mathrm{H}_{12} \mathrm{~N}^{+}$ion shows similar diurnal behavior as $\mathrm{CH}_{4} \mathrm{~N}^{+}$(not shown). The ions shown in Fig. 7a show measurable signals at all times, with diurnal patterns showing somewhat higher values for the $\mathrm{CHN}^{+}$ions in the late evening, night and early morning periods, while $\mathrm{NO}_{2}^{+}$is largest in the morning and early afternoon.
Figure $7 \mathrm{~b}$ shows two sulfur-containing ions: the inorganic sulfate-dominated $\mathrm{SO}^{+}(\mathrm{m} / z, 48)$ and the organosulfur ion $\mathrm{CH}_{3} \mathrm{SO}_{2}^{+}(\mathrm{m} / \mathrm{z}$, 96) which is thought to arise from methanesulfonic acid (MSA). Each ion, again, was chosen because its thermogram and diurnal pattern is representative of other important similar ions. The $\mathrm{SO}^{+}$thermogram is similar to that for sulfate (Fig. 4), while the $\mathrm{CH}_{3} \mathrm{SO}_{2}^{+}$ion shows much higher volatility, as expected for MSA. The diurnal variations in the thermograms of these sulfur-containing ions are small compared to their differences and show an opposite trend to the nitrogen-containing fragments in Fig. 7a. $\mathrm{SO}^{+}$shows higher MFR in the early morning than in the afternoon, especially between 83 and $142^{\circ} \mathrm{C}$, likely due to variations in the acidity effect discussed above. While not shown here, the MILAGRO SO${ }^{+}$thermogram has a similar trend in diurnal volatility, but with lower amplitude. Figure $7 \mathrm{~d}$ shows the diurnal trends of the signals of both ions, showing modest variations with time of the day.

\subsection{Organic volatility}

\subsubsection{Survey of OA thermograms}

A first observation for the $\mathrm{CH}^{+}$and $\mathrm{CHO}^{+}$organic ions is that the trends in organic MFR at $54^{\circ} \mathrm{C}$ (Fig. 6c, d) show less spread than for the ion groups discussed previously, with little dependence on $m / z$. Most of the ions scatter around MFR of 0.8 , with some individual outliers both noticeably above and below this line. The $\mathrm{CHO}^{+}$ion group shows slightly more variability in MFR. The most important individual ion in each campaign is $\mathrm{CO}_{2}^{+}(\mathrm{m} / \mathrm{z} 44)$, a marker for the OOA subclass of OA (Alfarra et al., 2004; Zhang et al., 2007a), and especially for the most oxidized OOA-1 subtype (Lanz et al., 2007; Ulbrich et al., 2009). $\mathrm{CO}_{2}^{+}$is both the most abundant ion in the ambient spectra, and the species that produce it are the least volatile among the organic species. $\mathrm{CH}_{2} \mathrm{O}_{2}^{+}$ $(\mathrm{m} / \mathrm{z}, 46)$ and $\mathrm{C}_{2} \mathrm{H}_{4} \mathrm{O}_{2}^{+}(\mathrm{m} / \mathrm{z}, 60)$, which are important ions for SOA and also for the biomass burning markers such as levoglucosan (Aiken et al., 2009a; Mohr et al., 2009), have MFR significantly $(>0.1)$ below the average $\mathrm{CHO}^{+}$line in both campaigns. $\mathrm{C}_{\mathrm{x}}^{+}$ions without additional bonded elements appear to be associated with less volatile species in both campaigns. The rest of the ions from both $\mathrm{CH}^{+}$and $\mathrm{CHO}^{+}$ion groups have volatilities that are very similar at the $54^{\circ} \mathrm{C}$ temperature. A weak trend is apparent for SOAR-1 where the $\mathrm{CHO}^{+}$group appears slightly more volatile than the $\mathrm{CH}^{+}$group while the opposite is true for MILAGRO, although the differences are minor. This suggests that while the OOA-1 aerosol has the lowest volatility, the HOA and the less aged and oxidized OOA-2 aerosol show similar volatility, as discussed in more detail below. A trend of decreasing MFR with increasing $\mathrm{m} / \mathrm{z}$ repeats approximately every 14 amu and can be seen in both SOAR-1 and MILAGRO, most apparent in the latter, indicating that the trend is correlated to trends in the chemical bonding structure reflected on 

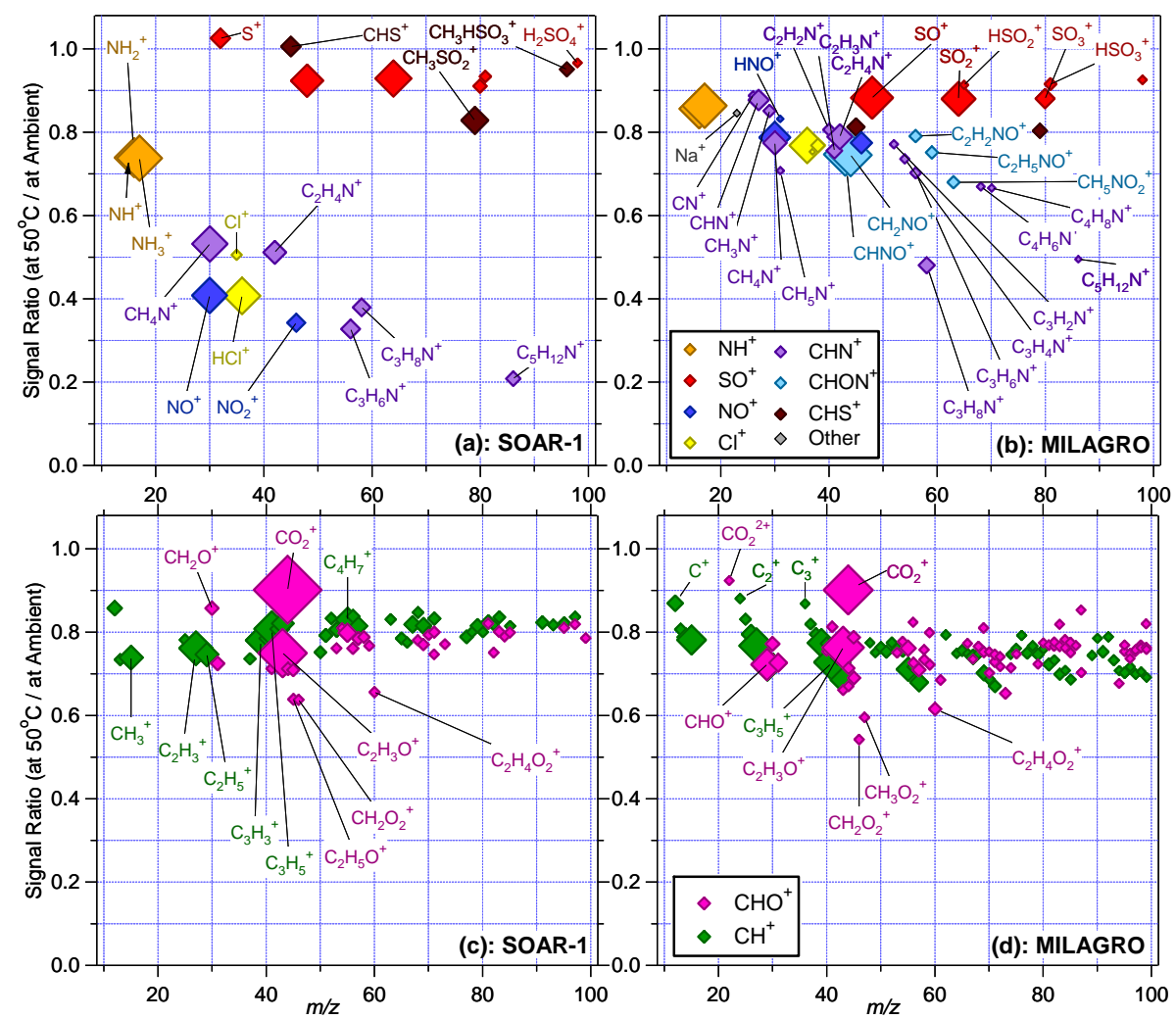

Fig. 6. MFR at $54^{\circ} \mathrm{C}$ is shown as a function of ion $\mathrm{m} / \mathrm{z}$. Top panels (a, b) show primarily inorganic ions with $\mathrm{N}-, \mathrm{S}-\mathrm{or} \mathrm{Cl}$-containing organic ions, and organic ions are shown on the bottom (c, d). SOAR-1 results shown on left panels (a, c) and MILAGRO on right panels (b, d). Marker color depicts ion group and is listed in the legend. Marker size indicates the relative contribution of each individual ion to the sum of the signals of all ions of the same group at ambient temperature, with the exception that $\mathrm{CH}^{+}$and $\mathrm{CHO}^{+}$were considered a single group for this purpose. Ion tags are grouped by molecular fragment trends.
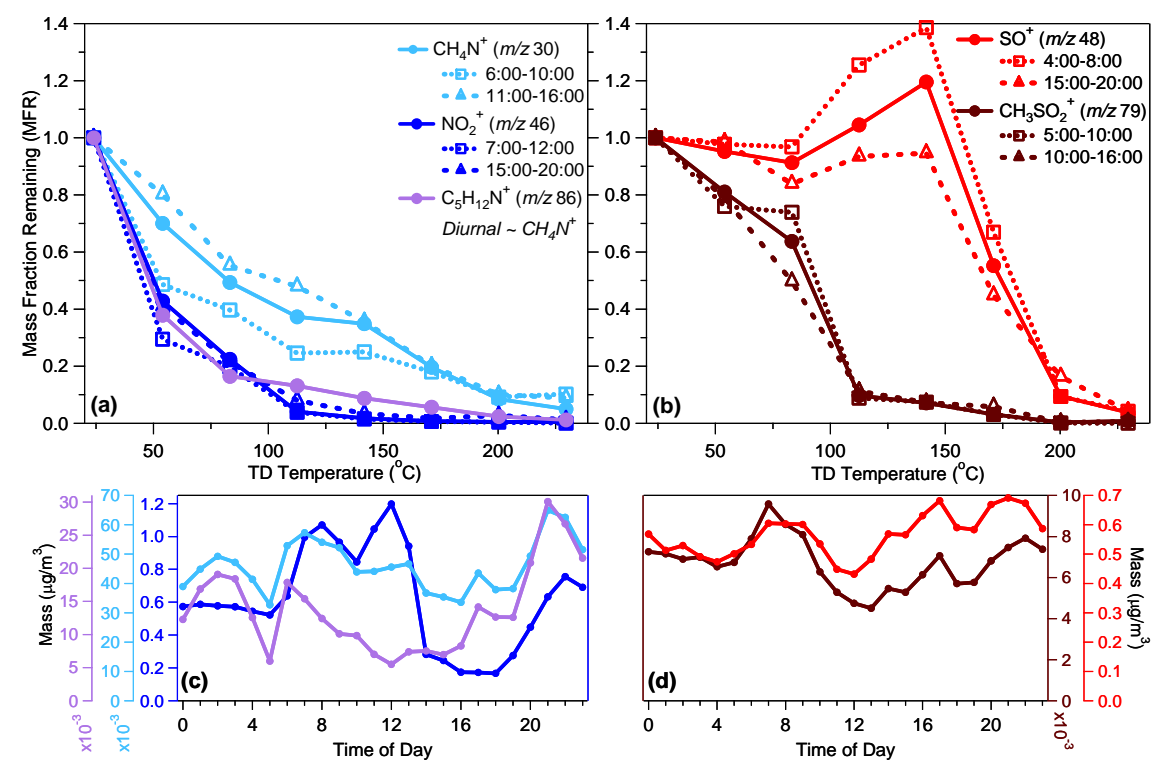

Fig. 7. Top panels (a-b) show thermograms of selected ions for SOAR-1 campaign total and diurnal averages. Bottom panels (c-d) show diurnal pattern of ion mass concentrations, averaged over the whole campaign. Averages of daily, morning, and afternoon shown for: (a) $\mathrm{CH}_{4} \mathrm{~N}^{+}$and $\mathrm{NO}_{2}^{+}$, (b) $\mathrm{SO}^{+}$and $\mathrm{CH}_{3} \mathrm{SO}_{2}^{+}$. Morning and afternoon periods are listed in the legend but vary between ions. Periods were chosen to represent maximum and minimum daily volatilities for each ion, respectively. Morning and afternoon averages for $\mathrm{C}_{5} \mathrm{H}_{12} \mathrm{~N}^{+}$are not shown to reduce graph clutter, but show similar trends as $\mathrm{CH}_{4} \mathrm{~N}^{+}$. 
the ion series (McLafferty and Turecek, 1993). Average MS at each TD temperature for MILAGRO are shown in Fig. S3, and highlight the relatively small variation in the mass spectrum for most ions, with the dominant exception of $\mathrm{m} / z 44$.

It has been suggested by several studies recently that oligomer formation can be important for laboratory and ambient SOA. Kalberer et al. (2004) used a SOA-formation experiment to show an increase in apparent volume fraction remaining after heating as aerosol age increased and concluded that this was due to oligomers forming in their smog chamber. Denkenberger et al. (2007) suggest that oligomer formation may be taking place within the TD at high temperatures due to the detection of signal patterns at high $\mathrm{m} / \mathrm{z}$ with their ATOFMS instrument, and suggest that the increased acidity for the residual aerosol (Fig. 5) may play a role in the oligomerization. We investigated the volatility of the species contributing to the high $\mathrm{m} / \mathrm{z}$ signals in the AMS, which potentially include oligomers (Kroll et al., 2006) but often are dominated by primary species (Zhang et al., 2005a; DeCarlo et al., 2008), by plotting the thermograms of higher $\mathrm{m} / \mathrm{z}$ values for each campaign after binning the ions into $50 \mathrm{amu}$ bins to increase S/N. The SOAR-1 plot in Supplemental Fig. S4a shows a slight increase in the MFR over the Total OA for the $\mathrm{m} / \mathrm{z}, 150-200$ average and increasing change up to $\mathrm{m} / \mathrm{z} 250$ 300. Denkenberger et al. (2007) report that the effect of increased signal at higher temperatures is most apparent in the negative ion spectrum above $300 \mathrm{amu}$. With only the positive ions analyzed by the AMS, the trend is still noticeable in our measurements during SOAR-1 for $m / z$ values plotted in this figure. The MILAGRO data, shown in Fig. S4b, indicate somewhat smaller increases in MFR starting again with the $\mathrm{m} / \mathrm{z}, 150-200$ curve, becoming more obvious in the $\mathrm{m} / \mathrm{z}, 200$ 250 bin. Unfortunately the $\mathrm{S} / \mathrm{N}$ of the thermograms for $\mathrm{m} / \mathrm{z}$ higher than those shown in the figures deteriorated and were unclear. These results suggest that indeed the species that dominate the larger fragment ions in the AMS are less volatile than the bulk of the OA and/or perhaps formed by chemistry in the TD at the higher temperatures.

\subsubsection{OA average volatility}

The average OA thermograms for both campaigns are plotted in Fig. 8a, b. The average decrease in MFR within the TD near ambient temperature is $\sim 0.6 \% \mathrm{~K}^{-1}$ for both campaigns. This information is useful to estimate the order of OA losses in heated aerosol instruments and aircraft sampling and the sensitivity of OA mass to changes in ambient temperature. Thermograms obtained for ambient OA, such as those shown in Fig. 8, are smooth and have similar shapes, indicating that they are produced by the evaporation of mixtures of compounds with a wide range of volatilities (Donahue et al., 2006; Huffman et al., 2008; Faulhaber et al., 2009). Due to these smooth shapes we utilize the temperature at which $50 \%$ of the OA mass has evaporated $\left(T_{50}\right)$ as a concise way of comparing volatility information across different experiments. $T_{50}$ for the average OA was 102 and $107^{\circ} \mathrm{C}$, for SOAR-1 and MILAGRO, respectively.

The effect of increased temperature on species evaporation is also a qualitative surrogate for the effect of increased dilution on evaporation. This is especially true near ambient temperature, although there are quantitative differences between the two processes especially for temperatures far from ambient, as the relative vapor pressures of different OA species stay the same during dilution but change during heating due to different enthalpies of vaporization (Dzepina et al., 2009).

The volatility of different OA components can also be analyzed through the thermograms for typical OA marker fragments from the HR-ToF-AMS (Fig. 8a, b). HOA is represented here by the $\mathrm{C}_{4} \mathrm{H}_{9}^{+}$ion (one of 2 dominant ions at $\mathrm{m} / \mathrm{z}, 57$ in urban air), which correlates well with urban combustion markers such as BC and CO (Zhang et al., 2005b; Aiken et al., 2009b; Ulbrich et al., 2009). The more oxidized OOA-1 is represented by the $\mathrm{CO}_{2}^{+}$ion (from which the signal from gas-phase $\mathrm{CO}_{2}$ has been subtracted), which dominates $m / z, 44$, while the relatively less oxidized OOA-2 is represented by $\mathrm{C}_{2} \mathrm{H}_{3} \mathrm{O}^{+}(\mathrm{m} / z, 43)$. Overall, the volatility of the $\mathrm{CO}_{2}^{+}$ion and its associated OOA-1 is the lowest of all $\mathrm{OA}$ ions in each campaign, while the volatility of the reduced HOA ions (e.g. $\mathrm{C}_{4} \mathrm{H}_{9}^{+}$) and the OOA-2 ions of intermediate oxidation (e.g. $\mathrm{C}_{2} \mathrm{H}_{3} \mathrm{O}^{+}$) showed much more similar behavior within each campaign. Other than $\mathrm{CO}_{2}^{+}$, most reduced and oxygenated ions at the same nominal mass have very similar MFR at temperatures below $140^{\circ} \mathrm{C}$, but the oxygenated ions usually show the lowest MFR at the highest temperatures (Figs. 1, 8a, b). The $\mathrm{CO}_{2}^{+}$ion (OOA-1 tracer) for SOAR-1 and MILAGRO showed $T_{50}$ values of 133 and $154^{\circ} \mathrm{C}$, respectively. The $\mathrm{C}_{4} \mathrm{H}_{9}^{+}$ion (HOA tracer), however, showed $T_{50}$ values of $94^{\circ} \mathrm{C}$ for SOAR- 1 and $85^{\circ} \mathrm{C}$ for MILAGRO while $\mathrm{C}_{2} \mathrm{H}_{3} \mathrm{O}^{+}$(OOA-2 tracer) showed $T_{50}$ values of 87 and $92^{\circ} \mathrm{C}$ for SOAR-1 and MILAGRO, respectively.

The $\mathrm{C}_{2} \mathrm{H}_{4} \mathrm{O}_{2}^{+}$ion at $m / z 60$ is one of the exceptions to the trend in OOA ion volatility for MILAGRO. It is commonly used as a tracer for biomass burning, although a fraction of it is due to organic acids in OOA/SOA (Aiken et al., 2008) and also to fatty acids in meat cooking aerosols (Mohr et al., 2009). This ion showed the fastest reduction with increasing temperature of any individual ions investigated during the MILAGRO campaign, and suggests relatively high volatility for BBOA, at least in Mexico City. The SOAR-1 campaign average of the same ion, however, did not show the same sharp decrease. Since biomass burning was not a significant contributor to the Riverside OA during SOAR-1 (Docherty et al., 2008), $\mathrm{C}_{2} \mathrm{H}_{4} \mathrm{O}_{2}^{+}$likely arises from components other than BBOA in this case. This suggests that the high volatility observed during MILAGRO is associated with the BBOA species that generate $\mathrm{C}_{2} \mathrm{H}_{4} \mathrm{O}_{2}^{+}$, and not with the SOA/OOA species that produce this ion.

Thermograms for total OA during MILAGRO periods either dominated by BBOA ( $\sim 60 \%$ of the OA mass during that period) or OOA-2 $(\sim 65 \%)$, or strongly influenced by 

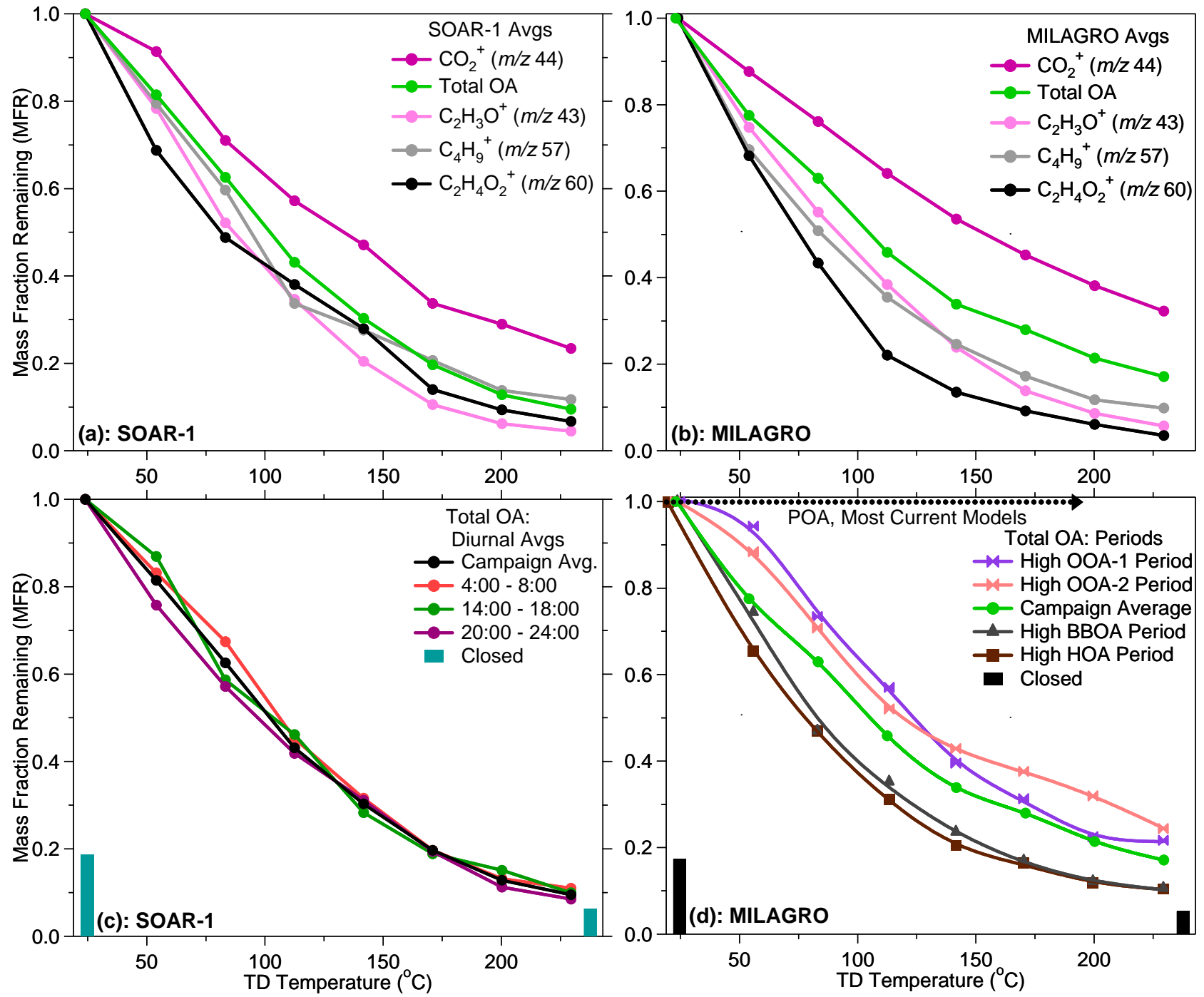

Fig. 8. Thermograms showing median mass fraction remaining (MFR) after passing through TD as a function of TD temperature. (a) Total OA and individual OA ions averaged over the SOAR-1 campaign. (b) Total OA and individual OA ions averaged over MILAGRO campaign. (c) Total OA from SOAR-1 for the whole campaign subdivided into three diurnally averaged periods. (d) Total OA from MILAGRO shown as a campaign average and for periods dominated by different OA components separated with PMF. Dashed black line shows representation of POA as non-volatile in most current aerosol models. Bars for both SOAR-1 and MILAGRO indicate the relative enhancement in mass remaining above background for the AMS closed signal at ambient temperature and $230^{\circ} \mathrm{C}$ as compared with the amount of signal in the AMS difference signal at ambient.

OOA-1 ( 40\%) or HOA ( $45 \%)$ are shown in Fig. 8d along with the MILAGRO campaign average. Although the different sampled air masses contained mixtures of the different OA types that combined to yield an average OA thermogram (Fig. 8d), HOA and BBOA appear to be more volatile than either OOA type. Mobility size distributions for the periods used in Fig. 8d are very similar (Supp. Fig. S5), indicating that kinetic evaporation differences due to size effects should be minor since the mass transfer rates are the same for particles of the same mobility diameter, independently of their physical shape (Rogak et al., 1991).
Figure 8c-d also shows the excess OA signal in the AMS background as a fraction of the mass spectrum mode signal under ambient conditions, with very similar results for MILAGRO and SOAR-1. The signal appearing in the background when the aerosol has been heated at $230^{\circ} \mathrm{C}$ is $\sim 5-$ $6 \%$ of the ambient signal, and this is our best estimate of the signal due to OA of vapor pressure low enough not to evaporate in the few second timescale of the MS mode. The excess signal under ambient (non-TD) analysis is $\sim 17-18 \%$ of the standard signal of ambient $\mathrm{OA}$ and corresponds to both the $\sim 5 \%$ low volatility OA, plus $\sim 12 \%$ signal from particles 
which may have bounced onto the colder surfaces in the vaporizer, and which are accounted for in an average sense with the CE and RIE corrections.

The method described here is necessarily limited to investigating volatility by measuring the loss of particle mass as temperature is increased. Because of the consistent and smooth shape of the thermograms, however, it is reasonable to extrapolate to temperatures below ambient to infer the amount of semivolatile species that would condense as temperature decreases. This approach should provide reasonable semi-quantitative estimates, at least for small decreases in temperature, and is of interest due to the current lack of any other method to quantify the total amount of semivolatile species in ambient air. The SOAR-1 thermograms shown in Fig. 8a indicate that an increase in temperature of $10^{\circ} \mathrm{C}$ from ambient results in the net loss of $\sim 6 \%$ of HOA mass $\left(\sim 0.6 \% \mathrm{~K}^{-1}\right.$ for small temperature increments), but only $\sim 3-5 \%$ of OOA mass $\left(\sim 0.3-0.5 \% \mathrm{~K}^{-1}\right)$. The MILAGRO thermograms show similar trends, with a wider difference between the two main OA component classes. Figure $8 \mathrm{~b}$ indicates a net loss of $\sim 8 \%$ of $\mathrm{HOA}$ mass $\left(\sim 0.8 \% \mathrm{~K}^{-1}\right)$ with a $10^{\circ} \mathrm{C}$ increase, but only $\sim 4-6 \%$ of OOA mass $\left(\sim 0.4-0.6 \% \mathrm{~K}^{-1}\right)$. We estimate that at least similar amounts of SVOCs are in equilibrium with each of the OA components. The availability of the primary SVOC mass qualitatively supports the mechanism proposed by Robinson et al. (2007) of SOA formation by gas-phase oxidation of primary SVOCs.

\subsubsection{OA diurnal variability}

SOAR-1 showed a clear diurnal cycle in OA composition (not shown) with OOA dominating during the afternoon and HOA comprising about half of the aerosol at the peak of the rush hour, while the variability between different days was smaller (Docherty et al., 2008). Thermograms of SOAR-1 total OA for different diurnal periods are shown in Fig. 8c. While the diurnal variability of OA composition and concentration is clear, there is very little diurnal variability in average OA volatility.

Figure 9 shows a similar analysis for the MILAGRO data. Figure 9a shows the diurnal profiles of both HOA and OOA mass concentrations while the total OA MFR (with a few periods of large BBOA impact removed) are shown in Fig. 9b. A diurnal cycle with higher volatility in the morning rush hour than in the afternoon is clear from Fig. 9b, suggesting that HOA is more volatile than OOA in Mexico City, contrasting with their similar volatility in Riverside. The reasons for the difference in the diurnal variability in Mexico City versus Riverside are discussed below.

\subsubsection{PMF results}

Until now all PMF analysis of AMS data, including from MILAGRO and SOAR-1 (Docherty et al., 2008; Aiken et

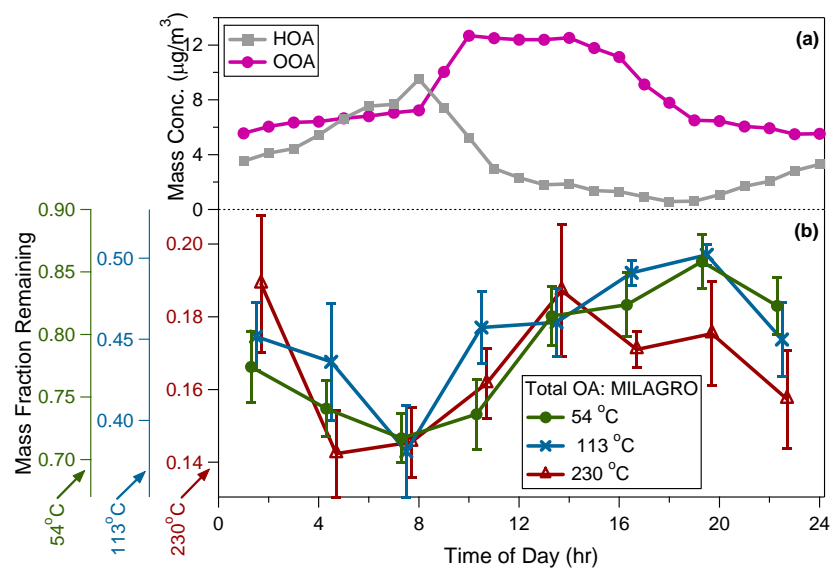

Fig. 9. (a) Average diurnal profile for HOA and OOA components for MILAGRO, determined by PMF. (b) Average diurnal profiles of remaining OA mass fraction after passing through the TD at three temperatures for MILAGRO. Each trace in (b) is plotted with its own y-axis scale to highlight diurnal trend. Error bars are the standard error of the mean.

al., 2009a), has included only ambient data without having used a thermodenuder in the analysis. Here, for the first time, the full SOAR-1 and MILAGRO datasets (ambient and thermally denuded data points) were included in the PMF analysis (TD-AMS-PMF). In addition to providing volatility profiles of all PMF-identified components, including the thermally denuded data enhances the contrast between time series of the different components and thus may facilitate their separation. However, including these data may also introduce additional variation in the MS which could distort the PMF fit. The results of PMF analysis from each campaign, both including and omitting the thermally denuded data points, are very consistent. As a result, it appears that any degradation of the PMF solution due to additional variation in the MS after TD-processing is more than compensated by the enhanced contrast between the different components. Thus we conclude that the PMF analysis of the TD-AMS data is successful at recovering the same components that are important under ambient-only conditions. In fact we will show that including the TD data enhances the application of PMF with respect to ambient only data and thus we recommend that future PMF analyses also use TD-AMS data whenever possible. More detailed discussion of PMF for these datasets are given elsewhere (Aiken et al., 2009a; Docherty et al., 2009), and so only the thermograms and MS of the identified OA components are discussed here.

Figure 10 shows PMF-identified OA components from the TD-AMS-PMF analysis plotted along with individual ions and other markers from each campaign. Supplemental Figs. S6 and S7 show corresponding MS for the components plotted in Fig. 10. Six components were identified from the SOAR-1 TD-AMS-PMF analysis, as discussed in more 
detail in Docherty et al. (2009): OOA-1, OOA-2, OOA-3, HOA, Local-OA-Amine Containing (LOA-AC), and LocalOA-2 (LOA-2).

The OOA-1 during SOAR-1 contributed $35 \%$ of total $\mathrm{OA}$ mass and correlates strongly with regionally-produced sulfate. The OOA-1 MS is consistent with a highly oxidized and more aged $\mathrm{OA}$ exhibiting high $\mathrm{CO}_{2}^{+}$as its most abundant ion. Figure 10a shows the SOAR-1 OOA-1 component thermogram along with those of $\mathrm{CO}_{2}^{+}$and total OA. This component has a significantly $(0.15-0.22)$ lower volatility relative to total OA and is somewhat less volatile than the $\mathrm{CO}_{2}^{+}$ion.

Figure $10 \mathrm{~b}$ shows thermograms for a second oxidized OA component (OOA-2), HOA, and LOA-2 components determined from the factor analysis (mass fractions of 31\%, $13 \%$ and 3\%, respectively). The thermograms of the HOA and OOA-2 components are similar, except at the highest temperatures when HOA shows a larger MFR. Again, this is consistent with trends from the individual ions that are important for each component. Individual ions of $\mathrm{C}_{2} \mathrm{H}_{3} \mathrm{O}^{+}$and $\mathrm{C}_{4} \mathrm{H}_{9}^{+}(\mathrm{m} / z, 43$ and 57, respectively) are shown as important contributors to the MS for OOA-2 and HOA, respectively. The identity and source of the LOA-2 component is unclear, but its thermogram is similar to those of HOA and OOA2. This component was identified as local based on its time series which was characterized by large, short-lived spikes (5-10 $\mathrm{min})$ predominately at night when wind speeds were low.

The final two components that were also robustly identified by PMF are OOA-3 (contributing 13\% OA mass) having a time series which correlates with that of aerosol nitrate, and another local (LOA-AC) component (4\% OA mass) with high contributions from the $\mathrm{CHN}^{+}$ion group and with the $\mathrm{C}_{5} \mathrm{H}_{12} \mathrm{~N}^{+}(m / z, 86)$ ion as a major peak. LOA-AC was again identified as local based on a time series that was characterized by large, short-duration spikes ( $<10 \mathrm{~min}$ ) predominately at night. Interestingly, the volatility of the nitrate-correlated OOA-3 compares well with $\mathrm{NO}^{+}$, shown here as a marker for total inorganic nitrate. Note that inorganic ions, including the $\mathrm{NO}^{+}$, are not included in the PMF input and thus should not influence the PMF fitting. The $\mathrm{NH}_{4}^{+}$balance discussed above, as well as the similarity between $\mathrm{NO}_{2}^{+}$to $\mathrm{NO}^{+}$ratios between ambient data and $\mathrm{NH}_{4} \mathrm{NO}_{3}$ calibrations do not suggest that a large contribution from organic nitrates to the $\mathrm{NO}_{\mathrm{x}}^{+}$signal during SOAR-1. As a result, the causes of the similar volatility are unclear and are perhaps coincidental, or related to mixing state. While the OOA-3 and traces for ions of nitrate fragments decay significantly (1.0 to 0.17$)$ by $112^{\circ} \mathrm{C}$, the LOA-AC component shows even lower MFR at low temperatures $\left(<80^{\circ} \mathrm{C}\right)$, but a small amount remaining at higher TD temperatures $\left(80-175^{\circ} \mathrm{C}\right)$. The time series of the LOA-AC component trace follows the general trend of the amine ion $\mathrm{C}_{5} \mathrm{H}_{12} \mathrm{~N}^{+}$, which is a major ion in its spectrum. Supplemental Fig. S8 shows the mass fraction remaining of each aerosol component as a function of temperature.
Four components were identified from the TD-AMS-PMF analysis of MILAGRO, discussed in more detail in Aiken et al. (2009a): OOA Total, HOA, and BBOA, and a local nitrogen-containing OA (LOA). Figure 10d shows the thermogram for the $\mathrm{OOA}_{\text {Total }}$ component identified, which shows lower volatility than the total OA, consistent with observations of total OA and individual ions discussed above. The $\mathrm{OOA}_{\text {Total }}$ component can be subdivided into a less-oxidized OOA-2 (51\% mass fraction, MF) component and a more oxidized OOA-1 (18\% MF) component. The OOA-2, with higher $\mathrm{m} / \mathrm{z}, 43$ to 44 ratio and stronger diurnal pattern than the OOA-1, shows nearly identical MFR as its associated marker ions. The OOA-1 component shows an MFR above that of the $\mathrm{CO}_{2}^{+}$ion and also above any other component in both studies, but more consistent with a highly aged OOA-1 than the OOA-2 component. The quality of separation of the OOA-1 and OOA-2 components from the OOA Total is somewhat poorer in the MILAGRO case than the SOAR-1 case, which is thought to be due to more variations in mass spectrometer tuning of the AMS during MILAGRO (Aiken et al., 2009a). The thermograms of HOA (14\% MF) and LOA (3\%) components are shown in Fig. 10e. Both components show higher volatility than $\mathrm{OOA}_{\text {Total }}$ or than either OOA subcomponent, except at the highest temperatures for HOA and are consistent with the discussion above. The spectrum of the LOA, again named for its spiky behavior and its presence predominantly in the morning, shows a dominance of reduced ions $\left(\mathrm{CH}^{+}\right.$group) and a strong signal from $\mathrm{C}_{3} \mathrm{H}_{8} \mathrm{~N}^{+}$ at $m / z 58$, which is typical of amines. The BBOA component shows higher volatility than all other MILAGRO OA components, which is consistent with the high volatility of one of its important tracer ions $\mathrm{C}_{2} \mathrm{H}_{4} \mathrm{O}_{2}^{+}$(also shown), as discussed previously. The BBOA detected in Mexico City has high volatility, consistent with its dominant source from pine forest burning (Aiken et al., 2009b) and the high volatility of the smoke from pine burning in laboratory experiments (Huffman et al., 2009). We note that BBOAs of much lower volatility are possible, and in fact the least-volatile OA detected to date with the TD-AMS setup is a BBOA from sage and rabbitbrush burning (Huffman et al., 2009).

We conclude that PMF is a powerful tool to analyze thermodenuder-AMS data. This analysis identifies similar components as an ambient-only PMF analysis and enhances component separation in some cases due to the additional contrast introduced into the time series by the TD cycle. In addition, the TD-AMS-PMF analysis also obtains thermograms of the identified component which provides useful information on the relative volatility of the different components.

\subsubsection{OA atomic ratios versus temperature}

As an alternative way of summarizing the change in the average chemical composition of the OA remaining after the TD, Fig. 11 shows the atomic ratios of oxygen- and 

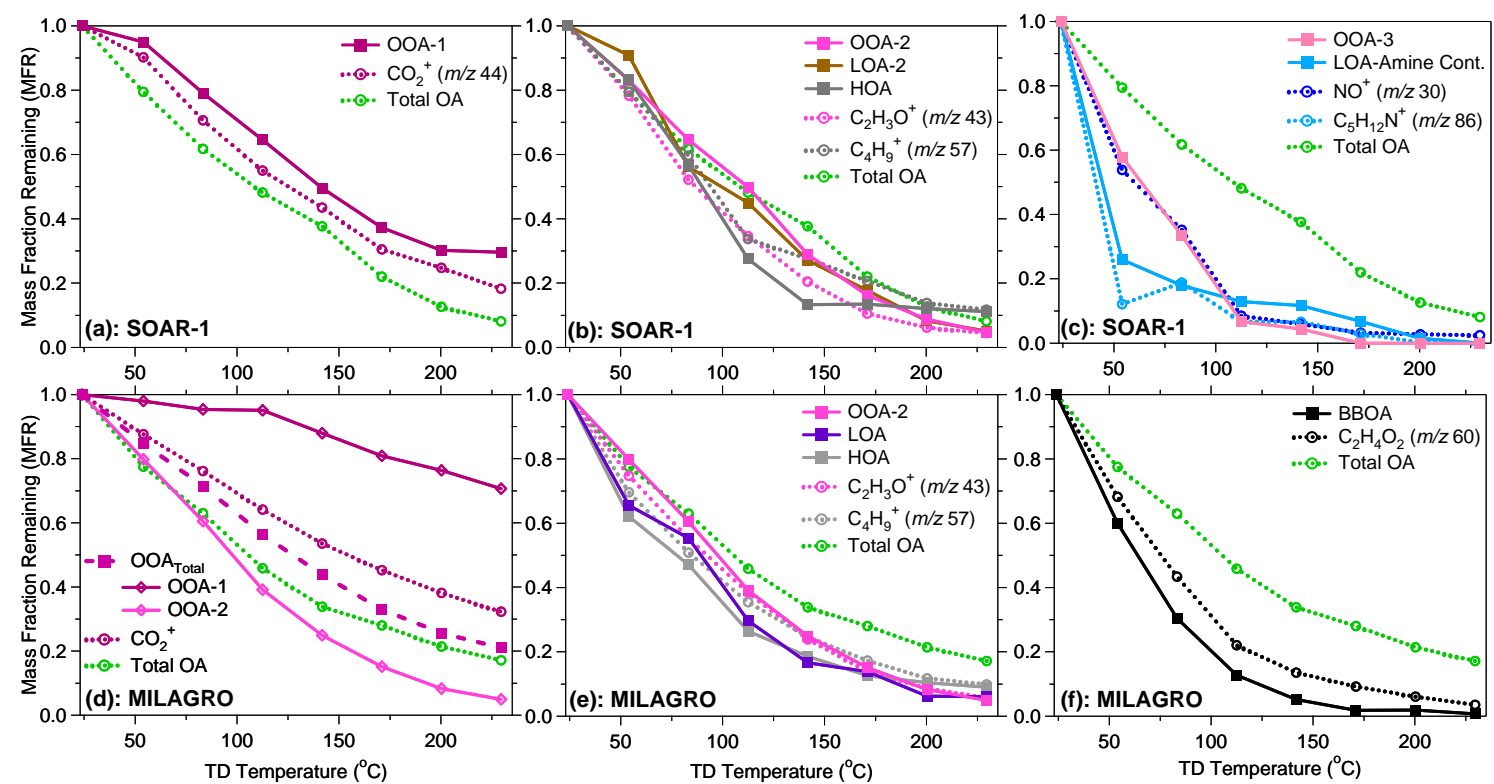

Fig. 10. Thermograms of PMF component outputs for the entire campaigns of SOAR-1 shown in top panel (a-c) and MILAGRO in the bottom panel $(\mathrm{d}-\mathrm{f})$. Solid lines show thermograms of PMF component outputs while dotted lines show individual ions from the same study that dominate each component. Total OA from the study is shown in each plot for comparison. (a) SOAR-1 OOA-1 component plotted alongside $\mathrm{CO}_{2}^{+}$. (b) HOA, OOA-2 and Local-OA-2 (LOA-2) components shown with OOA-2 ion $\mathrm{C}_{2} \mathrm{H}_{3} \mathrm{O}^{+}$and $\mathrm{HOA}_{\text {ion }} \mathrm{C}_{4} \mathrm{H}_{9}^{+}$. (c) OOA-3 and Local-OA-Amine Containing (LOA-AC) components shown with $\mathrm{NO}^{+}$and $\mathrm{C}_{5} \mathrm{H}_{12} \mathrm{~N}^{+}$. (d) MILAGRO OOA Total component shown with $\mathrm{CO}_{2}^{+}$and component subdivision into OOA-1 and OOA-2 solutions. (e) MILAGRO LOA, HOA, and OOA-2 (repeated) components shown with $\mathrm{C}_{2} \mathrm{H}_{3} \mathrm{O}^{+}$and $\mathrm{C}_{4} \mathrm{H}_{9}^{+}$. (f) MILAGRO BBOA component shown with $\mathrm{C}_{2} \mathrm{H}_{4} \mathrm{O}_{2}^{+}$, a marker for the levoglucosan molecule and representative of $\mathrm{BBOA}$.

hydrogen-to-carbon $(\mathrm{O} / \mathrm{C}$ and $\mathrm{H} / \mathrm{C})$ as a function of temperature. These ratios have been estimated from the highresolution spectra using the procedure recently developed by Aiken et al. $(2007,2008)$. In both studies the $\mathrm{O} / \mathrm{C}$ ratio increases steadily with temperature and is consistently $\sim 30 \%$ higher in the afternoon than in the morning for all temperatures measured. This is consistent with the lower volatility of more oxygenated species, and with the larger fraction of OOA and lower HOA and BBOA in the afternoons, as discussed above (Figs. 6 and 8) and in previous studies (Huffman et al., 2009; Shilling et al., 2009).

The lower panels in Fig. 11 show a reduction of the H/C ratio with increasing temperature for both campaigns. This is consistent with the higher volatility of more reduced species and the lowest volatility of the most oxygenated species as discussed above. Again, the average and diurnal trends of the curves from each campaign are similar, but the H/C values are shifted higher by approximately 0.1 in the MILAGRO campaign. This indicates that the relative concentration of reduced species such as HOA to the total OA is greater in Mexico City than in Riverside. This is consistent with the locations of the sites, which was inside of the city for MILAGRO, but $80 \mathrm{~km}$ downwind of the most intense urban sources for SOAR-1. The slopes of the curves, however, are very similar indicating that the changes in elemental composition after evaporation are very similar in both locations.
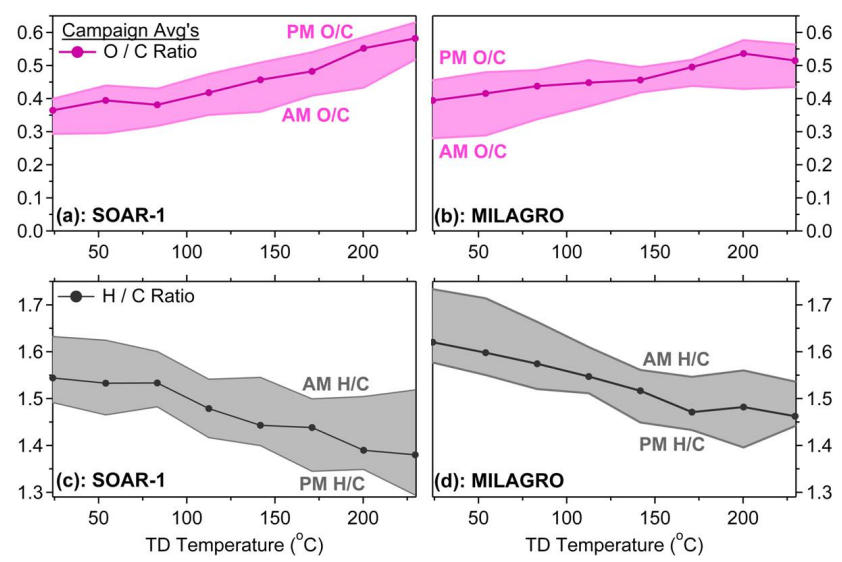

Fig. 11. Atomic ratios of oxygen-to-carbon $(\mathrm{O} / \mathrm{C})$ are shown for (a, c) SOAR-1 and $(\mathbf{b}, \mathbf{d})$ MILAGRO. Y-axis range is consistent in left and right panels. Pink colored region shows the diurnal $\mathrm{O} / \mathrm{C}$ range using morning (hours 4-8, local) as the lower bound and afternoon (hours 14-18) as the upper bound. Lower panels show H/C ratios and diurnal range of morning (upper bound) and afternoon (lower bound) ratios. 


\subsection{OA discussion}

The observation that OOA is of similar or lower volatility than that of HOA and BBOA is an important result. Almost all atmospheric models treat urban POA and primary BBOA as being completely non-volatile, with no allowance for evaporation with increasing temperature or dilution (i.e. the horizontal line at 1.0 in Fig. 8d). Our results show, however, that HOA and BBOA are similarly or even more volatile than other OA components in urban air. Furthermore, SOA, which dominates the OOA, is of similar or lower volatility than any other OA component. These results strongly support the suggestion by Robinson et al. (2007) that atmospheric models should treat all OA components as semivolatile.

The observations here that HOA and BBOA have similar or higher volatility than OOA, contradict 1-D and 2D GC-MS results (Hamilton et al., 2004; Williams et al., 2006), which suggest that SOA is significantly more volatile than POA. This discrepancy is most likely caused by an enhanced detection of reduced species $(\sim \mathrm{HOA})$ relative to OOA, due to lack of elution of most OOA from the traditionally non-polar GC columns used for OA analysis. This chemically-correlated detection bias may have led to overestimates of POA and underestimates of SOA in studies of atmospheric OA based on GC-MS measurements. Another possible explanation for the difference between the AMS and GC-MS results is that some of the more volatile oxygenated species detected in GC-MS studies may be not actually present in the aerosol, but instead may be formed by decomposition of less-volatile labile SOA species in the hot GC injector and column (Tobias et al., 2000; Williams et al., 2007).

\section{Conclusions}

The development of an automatic, fast temperature-stepping thermodenuder, coupled to a HR-ToF-AMS and SMPS has enabled the first direct investigation of chemically-resolved aerosol volatility in urban air. The system was deployed for approximately two weeks each as a part of larger megacity field campaigns in Riverside, CA (SOAR-1) and Mexico City (MILAGRO). Thermograms were acquired at eight temperature steps from ambient to $230^{\circ} \mathrm{C}$. The thermograms of the most important species and ions are broadly consistent across these two polluted urban sites. For both SOAR-1 and MILAGRO the inorganic nitrate showed the highest volatility among the inorganic species, and chloride showed high volatility at low temperatures, but a core of relatively nonvolatile material at high temperatures, especially in Mexico City. Sulfate showed low volatility, with a likely increase in AMS collection efficiency peaking at $142^{\circ} \mathrm{C}$. Further experiments involving the TD with monodisperse particles and the light scattering and beam width probes internal to the AMS will help investigate the source of the effects related to the relative increase in sulfate MFR at $90-140^{\circ} \mathrm{C}$. Ammonium showed little variation between field sites and was closely related to the thermograms of the bonded anions, except in that particle acidity increased as a function of TD temperature, likely due to decomposition of ammonium sulfate into ammonium bisulfate and ammonia upon heating and likely explaining the observed increase in sulfate collection efficiency. A small number of nitrogen- and sulfur-containing organic ions were shown to have volatility behavior distinct from one another and from inorganic ions. A generally broader range of volatility behavior for inorganic and $\mathrm{N}$-and S-containing OA ions was observed during SOAR-1 than during MILAGRO, contrasting with a consistently similar range among organic ions. OA ions showed less spread in volatility in comparison with inorganic ions, with even narrower variation for $\mathrm{CH}^{+}$group ions. The $\mathrm{CO}_{2}^{+}$ion showed the least volatility in every case measured, while for both ambient studies the less oxidized ions showed similar volatility. BBOA markers for $\mathrm{CH}_{2} \mathrm{O}_{2}^{+}$and $\mathrm{CH}_{4} \mathrm{O}_{2}^{+}$in Mexico City showed measurably higher volatility than other ions or classes of $\mathrm{OA}$. A new technique using the AMS background signal was demonstrated to quantify the fraction of species up to four ordersof-magnitude less volatile than those detectable in the MS mode, which for OA represent $\sim 5 \%$ of the NR OA signal. PMF analysis was used to separate individual components from both ambient locations. These components correlated well in both MS and time series with individual tracers and had similar thermograms in both locations studied. The use of a thermodenuder as a part of an AMS study can, therefore, be helpful not only to determine volatilities of aerosol components, but may also help separate PMF components more reliably. The $\mathrm{O} / \mathrm{C}$ ratio of the ambient $\mathrm{OA}$ measured increases steadily with temperature and is higher in the afternoon when photochemical oxidation is more active. This trend is reversed for the $\mathrm{H} / \mathrm{C}$ ratios, consistent with higher volatility for the reduced species and lower volatility for the more oxygenated species.

This study shows from direct observation of two urban, polluted megacities that all types of organic aerosols (OOA, HOA, and BBOA) should all be considered semi-volatile by air quality models. OOA was consistently the least volatile OA component and BBOA the most volatile. HOA was at least as volatile as OOA in all cases, and in some cases was substantially more so. Our results strongly support that models should treat all types of OA as semivolatile.

Acknowledgements. The authors would like to thank Nancy Marley and Jeffrey Gaffney, and David Snyder and Jamie Schauer for use of $\mathrm{BC} / \mathrm{EC}$ measurements from MILAGRO and SOAR-1, respectively, and Alex Laskin for measurements of crustal materials from MILAGRO. The authors would also like to thank J. R. Kimmel, E. Dunlea, M. Northway, and D. Salcedo for assistance in collecting data and C. Cappa and M. Fierz for useful discussions. We also thank the organizers of MILAGRO (S. Madronich and L. Molina), and SOAR-1 (K. Docherty and P. Ziemann). These studies were partially supported by grants DOE (BER, ASP Program) DE-FG02-05ER63981, EPA STAR R831080, RD-83216101-0, and 
R833747, NSF ATM-0449815 and ATM-0528634, ATM-0513116, NOAA grant NA08OAR4310565, by NASA fellowships NGT530516, NNG04GR06H, and NNG05GQ50H, and by EPA STAR fellowship FP-91650801.

Edited by: L. Molina

\section{References}

American Lung Association's State of the Air: http://lungaction. org/reports/sota07_cities.html, 2007.

Aiken, A. C., DeCarlo, P., and Jimenez, J.: Elemental Analysis of Organic Species with Electron Ionization High-Resolution Mass Spectrometry, Anal. Chem., 79, 8350-8358, 2007.

Aiken, A. C., Decarlo, P. F., Kroll, J. H., Worsnop, D. R., Huffman, J. A., Docherty, K., Ulbrich, I. M., Mohr, C., Kimmel, J. R., Sueper, D., Sun, Y., Zhang, Q., Trimborn, A., Northway, M., Ziemann, P. J., Canagaratna, M. R., Onasch, T. B., Alfarra, M. R., Prevot, A., Dommen, J., Duplissy, J., Metzger, A., Baltensperger, U., and Jimenez, J. L.: O/C and OM/OC Ratios of Primary, Secondary, and Ambient Organic Aerosols with a High Resolution Time-of-Flight Aerosol Mass Spectrometer, Environ. Sci. Technol., 42, 4478-4485, doi:10.1021/es703009q, 2008.

Aiken, A. C., de Foy, B., Wiedinmyer, C., and Jimenez, J. L.: Mexico City Aerosol Analysis during MILAGRO using High Resolution Aerosol Mass Spectrometry at the Urban Supersite (T0) - Part 2: Analysis of the Biomass Burning Contribution and teh Modern Carbon Fraction, Atmos. Chem. Phys. Discuss., in press, 2009a.

Aiken, A. C., Salcedo, D., Cubison, M. J., Huffman, J. A., DeCarlo, P. F., Ulbrich, I. M., Docherty, K. S., Sueper, D., Kimmel, J. R., Worsnop, D. R., Trimborn, A., Northway, M., Stone, E. A., Schauer, J. J., Volkamer, R. M., Fortner, E., de Foy, B., Wang, J., Laskin, A., Shutthanandan, V., Zheng, J., Zhang, R., Gaffney, J., Marley, N. A., Paredes-Miranda, G., Arnott, W. P., Molina, L. T., Sosa, G., and Jimenez, J. L.: Mexico City aerosol analysis during MILAGRO using high resolution aerosol mass spectrometry at the urban supersite (T0) - Part 1: Fine particle composition and organic source apportionment, Atmos. Chem. Phys., 9, 66336653, 2009b, http://www.atmos-chem-phys.net/9/6633/2009/.

Alfarra, M. R., Coe, H., Allan, J. D., Bower, K. N., Boudries, H., Canagaratna, M., Jimenez, J., Jayne, J., Garforth, A., Li, S. M., and Worsnop, D.: Characterization of Urban and Rural Organic Particulate In the Lower Fraser Valley Using Two Aerodyne Aerosol Mass Spectrometers, Atmos. Environ., 38, 57455758, 2004.

An, W. J., Pathak, R. K., Lee, B. H., and Pandis, S. N.: Aerosol volatility measurement using an improved thermodenuder: Application to secondary organic aerosol, J. Aerosol Sci., 38, 305314, 2007.

Bahreini, R., Jimenez, J. L., Wang, J., Flagan, R. C., Seinfeld, J. H., Jayne, J. T., and Worsnop, D. R.: Aircraft-based aerosol size and composition measurements during ACE-Asia using an Aerodyne aerosol mass spectrometer, J. Geophys. Res.-Atmos., 108, 8645, doi:10.1028/202JD003226, 2003.

Bidleman, T. F. Atmospheric Processes, Environ. Sci. Technol., 22, 361-367, 1988.

Biswas, P., Jones, C. L., and Flagan, R. C.: Distortion of Size Distributions by Condensation and Evaporation in Aerosol Instruments, Aerosol Sci. Technol., 7, 231-246, 1987.
Biswas, S., Verma, V., Schauer, J. J., Cassee, F. R., Cho, A. K., and Sioutas, C.: Oxidative Potential of Semi-Volatile and Non Volatile Particulate Matter (PM) from Heavy-Duty Vehicles Retrofitted with Emission Control Technologies, Environ. Sci. Technol., 43, 3905-3912, 2009.

Burtscher, H., Baltensperger, U., Bukowiecki, N., Cohn, P., Huglin, C., Mohr, M., Matter, U., Nyeki, S., Schmatloch, V., Streit, N., and Weingartner, E.: Separation of volatile and non-volatile aerosol fractions by thermodesorption: instrumental development and applications, J. Aerosol Sci., 32, 427-442, 2001.

Canagaratna, M. R., Jayne, J. T., Jimenez, J. L., Allan, J. D., Alfarra, M. R., Zhang, Q., Onasch, T. B., Drewnick, F., Coe, H., Middlebrook, A. M., Delia, A. E., Williams, L. R., Trimborn, A. M., Northway, M. J., DeCarlo, P. F., Kolb, C. E., Davidovits, P., and Worsnop, D. R.: Chemical and Microphysical Characterization of Ambient Aerosols with the Aerodyne Aerosol Mass Spectrometer, Mass Spectrom. Rev., 26, 185-222, 2007.

Christoforou, C. S., Salmon, L. G., Hannigan, M. P., Solomon, P. A., and Cass, G. R.: Trends in fine particle concentration and chemical composition in Southern California, J. Air Waste Manage., 50, 43-53, 2000.

Clarke, A. D.: A Thermo Optic Technique for Insitu Analysis of Size-Resolved Aerosol Physicochemistry, Atmos. Environ. A Gen, 25, 635-644, 1991.

Cross, E. S., Slowik, J. G., Davidovits, P., Allan, J. D., Worsnop, D. R., Jayne, J. T., Lewis, D. K., Canagaratna, M., and Onasch, T. B.: Laboratory and ambient particle density determinations using light scattering in conjunction with aerosol mass spectrometry, Aerosol Sci. Tech., 41, 343-359, 2007.

de Gouw, J. A. and Jimenez, J. L.: Organic Aerosols in the Earth's Atmosphere, Environ. Sci. Technol., doi:10.1021/es9006004, 2009.

DeCarlo, P., Slowik, J. G., Worsnop, D., Davidovits, P., and Jimenez, J.: Particle Morphology and Density Characterization by Combined Mobility and Aerodynamic Diameter Measurements. Part 1: Theory, Aerosol Sci. Tech., 38, 1185-1205, doi:10.1080/027868290903907, 2004.

DeCarlo, P. F., Kimmel, J. R., Trimborn, A., Northway, M. J., Jayne, J. T., Aiken, A. C., Gonin, M., Fuhrer, K., Horvath, T., Docherty, K. S., Worsnop, D. R., and Jimenez, J. L.: Field-deployable, high-resolution, time-of-flight aerosol mass spectrometer, Anal. Chem., 78, 8281-8289, 2006.

DeCarlo, P. F., Dunlea, E. J., Kimmel, J. R., Aiken, A. C., Sueper, D., Crounse, J., Wennberg, P. O., Emmons, L., Shinozuka, Y., Clarke, A., Zhou, J., Tomlinson, J., Collins, D. R., Knapp, D., Weinheimer, A. J., Montzka, D. D., Campos, T., and Jimenez, J. L.: Fast airborne aerosol size and chemistry measurements above Mexico City and Central Mexico during the MILAGRO campaign, Atmos. Chem. Phys., 8, 4027-4048, 2008,

http://www.atmos-chem-phys.net/8/4027/2008/.

Denkenberger, K. A., Moffet, R. C., Holecek, J. C., Rebotier, T. P., and Prather, K. A.: Real-time, single-particle measurements of oligomers in aged ambient aerosol particles, Environ. Sci. Technol., 41, 5439-5446, 2007.

Docherty, K. S., Stone, E. A., Ulbrich, I. M., Decarlo, P. F., Snyder, D. C., Schauer, J. J., Peltier, R. E., Weber, R. J., Murphy, S. M., Seinfeld, J. H., Eatough, D. J., and Jimenez, J. L.: Apportionment of Primary and Secondary Organic Aerosols in Southern California during the 2005 Study of Organic Aerosols 
in Riverside (SOAR), Environ. Sci. Technol., 42, 7655-7662, doi:10.1021/es8008166, 2008.

Docherty, K. S., Huffman, J. A., Ulbrich, I. M., et al.: Characterization of Ambient Southern California Submicron Organic Aerosol using Positive Matrix Factorization of High Resolution Aerosol Mass Spectra, Atmos. Chem. Phys. Discuss., in preparation, 2009.

Donahue, N. M., Robinson, A. L., Stanier, C. O., and Pandis, S. N.: Coupled partitioning, dilution, and chemical aging of semivolatile organics, Environ. Sci. Technol., 40, 2635-2643, 2006.

Drewnick, F., Schwab, J. J., Hogrefe, O., Peters, S., Husain, L., Diamond, D., Weber, R., and Demerjian, K. L.: Intercomparison and evaluation of four semi-continuous $\mathrm{PM}_{2.5}$ sulfate instruments, Atmos. Environ., 37, 3335-3350, 2003.

Dunlea, E. J., DeCarlo, P. F., Aiken, A. C., Kimmel, J. R., Peltier, R. E., Weber, R. J., Tomlison, J., Collins, D. R., Shinozuka, Y., McNaughton, C. S., Howell, S. G., Clarke, A. D., Emmons, L. K., Apel, E. C., Pfister, G. G., van Donkelaar, A., Martin, R. V., Millet, D. B., Heald, C. L., and Jimenez, J. L.: Evolution of Asian aerosols during transpacific transport in INTEX-B, Atmos. Chem. Phys. Discuss., 8, 15375-15461, 2008, http://www.atmos-chem-phys-discuss.net/8/15375/2008/.

Dzepina, K., Volkamer, R. M., Madronich, S., Tulet, P., Ulbrich, I. M., Zhang, Q., Cappa, C. D., Ziemann, P. J., and Jimenez, J. L.: Evaluation of recently-proposed secondary organic aerosol models for a case study in Mexico City, Atmos. Chem. Phys., 9, 5681-5709, 2009, http://www.atmos-chem-phys.net/9/5681/2009/.

Faulhaber, A. E., Thomas, B. M., Jimenez, J. L., Jayne, J. T., Worsnop, D. R., and Ziemann, P. J.: Characterization of a thermodenuder-particle beam mass spectrometer system for the study of organic aerosol volatility and composition, Atmos. Meas. Tech., 2, 15-31, 2009, http://www.atmos-meas-tech.net/2/15/2009/.

Fierz, M., Vernooij, M. G. C., and Burtscher, H.: An improved lowflow thermodenuder, J. Aerosol Sci., 38, 1163-1168, 2007.

Goetz, A., Preining, O., and Kallai, T.: The metastability of natural and urban aerosols, Pure Appl. Geophys., 50, 67-80, 1961.

Hallquist, M., Wenger, J. C., Baltensperger, U., Rudich, Y., Simpson, D., Claeys, M., Dommen, J., Donahue, N. M., George, C., Goldstein, A. H., Hamilton, J. F., Herrmann, H., Hoffmann, T., Iinuma, Y., Jang, M., Jenkin, M. E., Jimenez, J. L., Kiendler-Scharr, A., Maenhaut, W., McFiggans, G., Mentel, Th. F., Monod, A., Prévôt, A. S. H., Seinfeld, J. H., Surratt, J. D., Szmigielski, R., and Wildt, J.: The formation, properties and impact of secondary organic aerosol: current and emerging issues, Atmos. Chem. Phys., 9, 5155-5235, 2009, http://www.atmos-chem-phys.net/9/5155/2009/.

Hamilton, J. F., Webb, P. J., Lewis, A. C., Hopkins, J. R., Smith, S., and Davy, P.: Partially oxidised organic components in urban aerosol using GCXGC-TOF/MS, Atmos. Chem. Phys., 4, 12791290, 2004, http://www.atmos-chem-phys.net/4/1279/2004/.

Heald, C. L., Jacob, D. J., Park, R. J., Russell, L. M., Huebert, B. J., Seinfeld, J. H., Liao, H., and Weber, R. J.: A large organic aerosol source in the free troposphere missing from current models, Geophys. Res. Lett., 32, L18809, doi:10.1029/2005gl023831, 2005.

Hering, S. and Cass, G.: The magnitude of bias in the measurement of $\mathrm{PM}_{2.5}$ arising from volatilization of particulate nitrate from teflon filters, J. Air Waste Manage., 49, 725-733, 1999.

Herndon, S.C., Onasch, T. B., Wood, E. C., Kroll, J. H., Canagaratna, M. R., Jayne, J. T., Zavala, M. A., Knighton, W. B., Mazzoleni, C., Dubey, M. K., Ulbrich, I. M., Jimenez, J. L., Seila, R., de Gouw, J. A., de Foy, B., Fast, J., Molina, L. T., Kolb, C. E., and Worsnop, D. R.: The Correlation of Secondary Organic Aerosol with Odd Oxygen in a Megacity Outflow, Geophys. Res. Lett., 35, L15804, doi:10.1029/2008GL034058, 2008.

Hildemann, L. M., Cass, G. R., and Markowski, G. R.: A Dilution Stack Sampler for Collection of Organic Aerosol Emissions Design, Characterization and Field-Tests, Aerosol Sci. Technol., 10, 193-204, 1989

Huffman, J. A., Jayne, J. T., Drewnick, F., Aiken, A. C., Onasch, T., Worsnop, D. R., and Jimenez, J. L.: Design, modeling, optimization, and experimental tests of a particle beam width probe for the aerodyne aerosol mass spectrometer, Aerosol Sci. Technol., 39, 1143-1163, doi:10.1080/02786820500423782, 2005.

Huffman, J. A., Ziemann, P. J., Jayne, J. T., Worsnop, D R., and Jimenez, J. L.: Development and Characterization of a Fast-Stepping/Scanning Thermodenuder for ChemicallyResolved Aerosol Volatility Measurements, Aerosol Sci. Technol., 42, 395-407, doi:10.1080/02786820802104981, 2008.

Huffman, J. A., Mohr, C., Ulbrich, I. M., Cubison, M J., Docherty, K. S., Onasch, T. B., Ziemann, P. J., and Jimenez, J. L.: Chemically-Resolved Volatility Measurements of Aerosol Sources, Environ. Sci. Technol., 43, 5351-5357, doi:10.1021/es803539d, 2009.

Hughes, L. S., Allen, J. O., Bhave, P., Kleeman, M. J., Cass, G. R. Liu, D. Y., Fergenson, D. F., Morrical, B. D., and Prather, K. A.: Evolution of atmospheric particles along trajectories crossing the Los Angeles basin, Environ. Sci. Technol., 34, 3058-3068, 2000.

Jayne, J. T., Leard, D. C., Zhang, X. F., Davidovits, P., Smith, K A., Kolb, C. E., and Worsnop, D. R.: Development of an aerosol mass spectrometer for size and composition analysis of submicron particles, Aerosol Sci. Technol., 33, 49-70, 2000.

Jennings, S. G. and O'Dowd, C. D.: Volatility of Aerosol at Mace Head, on the West-Coast of Ireland, J. Geophys. Res.-Atmos., 95, 13937-13948, 1990.

Jennings, S. G., O’Dowd, C. D., Cooke, W. F., Sheridan, P. J., and Cachier, H.: Volatility of Elemental Carbon, Geophys. Res. Lett., 21, 1719-1722, 1994.

Jimenez, J. L., Jayne, J. T., Shi, Q., Kolb, C. E., Worsnop, D R., Yourshaw, I., Seinfeld, J. H., Flagan, R. C., Zhang, X. F., Smith, K. A., Morris, J. W., and Davidovits, P.: Ambient aerosol sampling using the Aerodyne Aerosol Mass Spectrometer, J. Geophys. Res.-Atmos., 108, 8425, doi:10.1029/2001JD001213, 2003.

Johnson, K. S., Laskin, A., Jimenez, J. L., Shutthanandan, V., Molina, L. T., Salcedo, D., Dzepina, K., and Molina, M. J.: Comparative analysis of urban atmospheric aerosol by particleinduced X-ray emission (PIXE), proton elastic scattering analysis (PESA), and aerosol mass spectrometry (AMS), Environ. Sci. Technol., 42, 6619-6624, doi:10.1021/es800393e, 2008.

Kalberer, M., Paulsen, D., Sax, M., Steinbacher, M., Dommen, J., Prevot, A. S. H., Fisseha, R., Weingartner, E., Frankevich, V., Zenobi, R., and Baltensperger, U.: Identification of polymers as major components of atmospheric organic aerosols, Science, $303,1659-1662,2004$ 
Kanakidou, M., Seinfeld, J. H., Pandis, S. N., Barnes, I., Dentener, F. J., Facchini, M. C., Van Dingenen, R., Ervens, B., Nenes, A., Nielsen, C. J., Swietlicki, E., Putaud, J. P., Balkanski, Y., Fuzzi, S., Horth, J., Moortgat, G. K., Winterhalter, R., Myhre, C. E. L., Tsigaridis, K., Vignati, E., Stephanou, E. G., and Wilson, J.: Organic aerosol and global climate modelling: a review, Atmos. Chem. Phys., 5, 1053-1123, 2005,

http://www.atmos-chem-phys.net/5/1053/2005/.

Kreidenweis, S. M., McInnes, L. M., and Brechtel, F. J.: Observations of aerosol volatility and elemental composition at Macquarie Island during the First Aerosol Characterization Experiment (ACE 1), J. Geophys. Res.-Atmos., 103, 16511-16524, 1998.

Kroll, J. H., Ng, N. L., Murphy, S. M., Flagan, R. C., and Seinfeld, J. H.: Secondary Organic Aerosol Formation from Isoprene Photooxidation, Environ. Sci. Technol., 40, 1869-1877, 2006.

Lanz, V. A., Alfarra, M. R., Baltensperger, U., Buchmann, B., Hueglin, C., and Prévôt, A. S. H.: Source apportionment of submicron organic aerosols at an urban site by factor analytical modelling of aerosol mass spectra, Atmos. Chem. Phys., 7, 15031522, 2007, http://www.atmos-chem-phys.net/7/1503/2007/.

Larson, T. V., Ahlquist, N. C., Weiss, R. E., Covert, D. S., and Waggoner, A. P.: Chemical Speciation of $\mathrm{H} 2 \mathrm{SO} 4-\left(\mathrm{NH}_{4}\right) 2 \mathrm{SO}_{4}$ Particles Using Temperature and Humidity Controlled Nephelometry, Atmos. Environ., 16, 1587-1590, 1982.

Lipsky, E. M. and Robinson, A. L.: Effects of Dilution on Fine Particle Mass and Partitioning of Semivolatile Organics in Diesel Exhaust and Wood Smoke, Environ. Sci. Technol., 40, 155-162, 2006

Malm, W. C., Sisler, J. F., Huffman, D., Eldred, R. A., and Cahill, T. A.: Spatial and Seasonal Trends in Particle Concentration and Optical Extinction in the United States, J. Geophys. Res.-Atmos., 99, 1347-1370, 1994.

Matthew, B. M., Middlebrook, A. M., and Onasch, T. B.: Collection Efficiencies in an Aerodyne Aerosol Mass Spectrometer as a Function of Particle Phase for Laboratory Generated Aersols, Aerosol Sci. Technol., 42, 884-898, doi:10.1080/02786820802356797, 2008.

McLafferty, F. W. and Turecek, F.: Interpretation of Mass Spectra, 4th Edition ed., University Science Books, Sausalito, CA, 1993.

Meyer, M. B., Patashnick, H., Ambs, J. L., and Rupprecht, E.: Development of a sample equilibration system for the TEOM continuous PM monitor, J. Air Waste Manage., 50, 1345-1349, 2000.

Moffet, R. C., de Foy, B., Molina, L. T., Molina, M. J., and Prather, K. A.: Measurement of ambient aerosols in northern Mexico City by single particle mass spectrometry, Atmos. Chem. Phys., 8, 4499-4516, 2008,

http://www.atmos-chem-phys.net/8/4499/2008/.

Mohr, C., Huffman, J. A., Cubison, M. J., Aiken, A. C., Docherty, K. S., Kimmel, J. R., Hannigan, M., and Jimenez, J. L.: Characterization of Primary Organic Aerosol Emissions from Meat Cooking, Trash Burning, and Mobile Sources with HighResolution Aerosol Mass Spectrometry and Comparison with Ambient and Chamber Observations, Environ. Sci. Technol., 43, 2443-2449, doi:10.1021/es8011518, 2009.

Molina, L. T., Kolb, C. E., de Foy, B., Lamb, B. K., Brune, W. H., Jimenez, J. L., Ramos-Villegas, R., Sarmiento, J., ParamoFigueroa, V. H., Cardenas, B., Gutierrez-Avedoy, V., and Molina,
M. J.: Air quality in North America's most populous city overview of the MCMA-2003 campaign, Atmos. Chem. Phys., 7, 2447-2473, 2007,

http://www.atmos-chem-phys.net/7/2447/2007/.

Nemitz, E., Jimenez, J. L., Huffman, J. A., Canagaratna, M. R., Worsnop, D. R., and Guenther, A. B.: An eddy-covariance system for the measurement of surface/atmosphere exchange fluxes of submicron aerosol chemical species - first application above an urban area, Aerosol Sci. Tech., 42, 636-657, 2008.

Odum, J. R., Jungkamp, T. P. W., Griffin, R. J., Forstner, H. J. L., Flagan, R. C., and Seinfeld, J. H.: Aromatics, reformulated gasoline, and atmospheric organic aerosol formation, Environ. Sci. Technol., 31, 1890-1897, 1997.

Orsini, D. A., Wiedensohler, A., Stratmann, F., and Covert, D. S.: A new volatility tandem differential mobility analyzer to measure the volatile sulfuric acid aerosol fraction, J. Atmos. Ocean. Tech., 16, 760-772, 1999.

Paredes-Miranda, G., Arnott, W. P., Jimenez, J. L., Aiken, A. C., Gaffney, J. S., and Marley, N. A.: Primary and secondary contributions to aerosol light scattering and absorption in Mexico City during the MILAGRO 2006 campaign, Atmos. Chem. Phys., 9, 3721-3730, 2009,

http://www.atmos-chem-phys.net/9/3721/2009/.

Pinnick, R. G., Jennings, S. G., and Fernandez, G.: Volatility of Aerosols in the Arid Southwestern United-States, J. Atmos. Sci., 44, 562-576, 1987.

Querol, X., Pey, J., Minguillón, M. C., Pérez, N., Alastuey, A., Viana, M., Moreno, T., Bernabé, R. M., Blanco, S., Cárdenas, B., Vega, E., Sosa, G., Escalona, S., Ruiz, H., and Artíñano, B.: PM speciation and sources in Mexico during the MILAGRO-2006 Campaign, Atmos. Chem. Phys., 8, 111-128, 2008, http://www.atmos-chem-phys.net/8/111/2008/.

Quinn, P. K., Bates, T. S., Coffman, D., Onasch, T. B., Worsnop, D. R., Baynard, T., de Gouw, J. A., Golden, P. D., Kuster, W. C., Williams, E., Roberts, J. M., Lerner, B., Stohl, A., Pettersson, A., and Lovejoy, E. R.: Impacts of Sources and Aging on Submicrometer Aerosol Properties in the Maine Boundary Layer Across the Gulf of Maine, J. Geophys. Res., 111, D23S36, doi:10.1029/2006JD007582, 2006.

Robinson, A. L., Donahue, N. M., Shrivastava, M. K., Weitkamp, E. A., Sage, A. M., Grieshop, A. P., Lane, T. E., Pierce, J. R., and Pandis, S. N.: Rethinking organic aerosols: Semivolatile emissions and photochemical aging, Science, 315, 1259-1262, 2007.

Rogak, S. N., Baltensperger, U., and Flagan, R. C.: Measurement of Mass Transfer to Agglomerate Aerosols, Aerosol Sci. Technol., 14, 447-458, 1991.

Rogge, W. F., Mazurek, M. A., Hildemann, L. M., Cass, G. R., and Simoneit, B. R. T.: Quantification of Urban Organic Aerosols at a Molecular-Level - Identification, Abundance and SeasonalVariation, Atmos. Environ., 27, 1309-1330, 1993.

Salcedo, D., Onasch, T. B., Dzepina, K., Canagaratna, M. R., Zhang, Q., Huffman, J. A., DeCarlo, P. F., Jayne, J. T., Mortimer, P., Worsnop, D. R., Kolb, C. E., Johnson, K. S., Zuberi, B., Marr, L. C., Volkamer, R., Molina, L. T., Molina, M. J., Cardenas, B., Bernabé, R. M., Márquez, C., Gaffney, J. S., Marley, N. A., Laskin, A., Shutthanandan, V., Xie, Y., Brune, W., Lesher, R., Shirley, T., and Jimenez, J. L.: Characterization of ambient aerosols in Mexico City during the MCMA-2003 campaign with Aerosol Mass Spectrometry: results from the CENICA Super- 
site, Atmos. Chem. Phys., 6, 925-946, 2006

http://www.atmos-chem-phys.net/6/925/2006/.

Salcedo, D., Onasch, T. B., Canagaratna, M. R., Dzepina, K., Huffman, J. A., Jayne, J. T., Worsnop, D. R., Kolb, C. E., Weimer, S., Drewnick, F., Allan, J. D., Delia, A. E., and Jimenez, J. L.: Technical Note: Use of a beam width probe in an Aerosol Mass Spectrometer to monitor particle collection efficiency in the field, Atmos. Chem. Phys., 7, 549-556, 2007, http://www.atmos-chem-phys.net/7/549/2007/.

Saleh, R., Walker, J., and Khlystov, A.: Determination of saturation pressure and enthalpy of vaporization of semi-volatile aerosols: The integrated volume method, J. Aerosol Sci., 39, 876-887, 2008

Shilling, J. E., Chen, Q., King, S. M., Rosenoern, T., Kroll, J. H., Worsnop, D. R., DeCarlo, P. F., Aiken, A. C., Sueper, D., Jimenez, J. L., and Martin, S. T.: Loading-dependent elemental composition of $\alpha$-pinene SOA particles, Atmos. Chem. Phys., 9, 771-782, 2009, http://www.atmos-chem-phys.net/9/771/2009/.

Slowik, J. G., Stainken, K., Davidovits, P., Williams, L. R., Jayne, J., Kolb, C. E., Worsnop, D., Rudich, Y., DeCarlo, P., and Jimenez, J.: Particle Morphology and Density Characterization by Combined Mobility and Aerodynamic Diameter Measurements. Part 2: Application to Combustion Generated Soot Particles as a Function of Fuel Equivalence Ratio, Aerosol Sci. Technol., 38, 1206-1222, 2004.

Snyder, D. C. and Schauer, J. J.: An Inter-Comparison of Two Black Carbon Aerosol Instruments and a Semi-Continuous Elemental Carbon Instrument in the Urban Environment, Aerosol Sci. Technol., 41, 463-474, 2007.

Takegawa, N., Miyazaki, Y., Kondo, Y., Miyakawa, T., Jimenez, J. L., Jayne, J. T., Worsnop, D. R., Allan, J. D., and Weber, R. J.: Characterization of an Aerodyne Aerosol Mass Spectrometer (AMS): Intercomparison with other aerosol instruments, Aerosol Sci. Technol., 39, 760-770, 2005.

Tanaka, P. L., Riemer, D. D., Chang, S. H., Yarwood, G., McDonald-Buller, E. C., Apel, E. C., Orlando, J. J., Silva, P. J., Jimenez, J. L., Canagaratna, M. R., Neece, J. D., Mullins, C. B., and Allen, D. T.: Direct evidence for chlorine-enhanced urban ozone formation in Houston, Texas, Atmos. Environ., 37, 1393-1400, doi:10.1016/s1352-2310(02)01007-5, 2003.

Tobias, H. J., Docherty, K. S., Beving, D. E., and Ziemann, P. J.: Effect of relative humidity on the chemical composition of secondary organic aerosol formed from reactions of 1-tetradecene and O-3, Environ. Sci. Technol., 34, 2116-2125, 2000.

Tolocka, M. P. and Turpin, B. J.: Contribution of organosulfur compounds to organic aerosol mass, 28th Annual Conference of the American Association for Aerosol Research, Minneapolis, MN, October 2009.

Twomey, S.: On the composition of cloud nuclei in the northeastern United States, Journal de Recherches Atmospheriques, 3, 281285,1968

Ulbrich, I. M., Canagaratna, M. R., Zhang, Q., Worsnop, D. R., and Jimenez, J. L.: Interpretation of organic components from Positive Matrix Factorization of aerosol mass spectrometric data, Atmos. Chem. Phys., 9, 2891-2918, 2009, http://www.atmos-chem-phys.net/9/2891/2009/.

Villani, P., Picard, D., Marchand, N., and Laj, P.: Design and Validation of a 6-Volatility Tandem Differential Mobility Analyzer (VTDMA), Aerosol Sci. Technol., 41, 898-906, 2007.
Volkamer, R., Jimenez, J. L., San Martini, F., Dzepina, K., Zhang, Q., Salcedo, D., Molina, L. T., Worsnop, D. R., and Molina, M. J.: Secondary organic aerosol formation from anthropogenic air pollution: Rapid and higher than expected, Geophys. Res. Lett., 33, L17811, doi:10.1029/2006GL026899, 2006.

Volkamer, R., San Martini, F., Molina, L. T., Salcedo, D., Jimenez, J. L., and Molina, M. J.: A Missing Sink for Gas-Phase Glyoxal in Mexico City: Formation of Secondary Organic Aerosol, Geophys. Res. Lett., 34, L19807, doi:10.1029/2007GL030752, 2007.

Wehner, B., Philippin, S., and Wiedensohler, A.: Design and calibration of a thermodenuder with an improved heating unit to measure the size-dependent volatile fraction of aerosol particles, J. Aerosol Sci., 33, 1087-1093, 2002.

Williams, B. J., Goldstein, A. H., Kreisberg, N. M., and Hering, S. V.: An in-situ instrument for speciated organic composition of atmospheric aerosols: Thermal Desorption Aerosol GC/MS-FID (TAG), Aerosol Sci. Technol., 40, 627-638, 2006.

Williams, B. J., Goldstein, A. H., Millet, D. B., Holzinger, R., Kreisberg, N. M., Hering, S. V., Allan, J. D., Worsnop, D. R., Jimenez, J. L., and White, A. B.: Chemical Speciation of Organic Aerosol during ICARTT 2004: Results from InSitu Measurements, J. Geophys. Res.-Atmos., 112, D10S26, doi:10.1029/2006JD007601, 2007.

Wilson, J. C. and Seebaugh, W. R.: Chapter 30: Measurement of Aerosol from Aircraft, in: Aerosol Measurement: Principles, Techniques, and Applications, 2nd edn., edited by: Baron, P. A. and Willeke, K., Wiley-Interscience, p. 894, 2001.

Zelenyuk, A., Yang, J., Song, C., Zaveri, R. A., and Imre, D.: A New Real-Time Method for Determining Particles' Sphericity and Density: Application to Secondary Organic Aerosol Formed by Ozonolysis of $\alpha$-Pinene, Environ. Sci. Technol., 42, 8033 8038, 2008.

Zhang, Q., Alfarra, M. R., Worsnop, D. R., Allan, J. D., Coe, H., Canagaratna, M. R., and Jimenez, J. L.: Deconvolution and quantification of hydrocarbon-like and oxygenated organic aerosols based on aerosol mass spectrometry, Environ. Sci. Technol., 39, 4938-4952, 2005a.

Zhang, Q., Worsnop, D. R., Canagaratna, M. R., and Jimenez, J. L.: Hydrocarbon-like and oxygenated organic aerosols in Pittsburgh: insights into sources and processes of organic aerosols, Atmos. Chem. Phys., 5, 3289-3311, 2005b,

http://www.atmos-chem-phys.net/5/3289/2005/.

Zhang, Q., Jimenez, J., Canagaratna, M., Allan, J. D., Coe, H., Ulbrich, I., Alfarra, M. R., Takami, A., Middlebrook, A. M., Sun, Y. L., Dzepina, K., Dunlea, E., Docherty, K., DeCarlo, P., Salcedo, D., Onasch, T. B., Jayne, J., Miyoshi, T., Shimono, A., Hatakeyama, S., Takegawa, N., Kondo, Y., Schneider, J., Drewnick, F., Weimer, S., Demerjian, K. L., Williams, P., Bower, K. N., Bahreini, R., Cottrell, L., Griffin, R. J., Rautiainen, J., and Worsnop, D.: Ubiquity and Dominance of Oxygenated Species in Organic Aerosols in Anthropogenically-Influenced Northern Hemisphere Mid-Latitudes, Geophys. Res. Lett., 34, L13801, doi:10.1029/2007GL029979, 2007a.

Zhang, Q., Jimenez, J. L., Worsnop, D. R., and Canagaratna, M.: A Case Study of Urban Particle Acidity and its Effect on Secondary Organic Aerosol, Environ. Sci. Technol., 41, 3213-3219, doi:10.1021/es061812j, 2007b. 